\title{
Effect of Teachers' Job Satisfaction on Their Commitment: In Case of Selected Governmental Preparatory Schools of Bale Zone in Focus
}

\author{
*Tahir Kedir ${ }^{1} \quad$ Tesfaye Hirpasa ${ }^{1} \quad$ Umer Abdela $^{1}$ \\ Madda Walabu University, Bale Robe, Ethiopia
}

\begin{abstract}
The purpose of this study was to investigate the effects of teachers' job satisfactions on their commitment in selected governmental Preparatory Schools of Bale Zone. Hence, it examined the levels of teachers' job satisfaction, the relation with their commitments as well as the effect of teachers' job satisfaction on their commitment in the selected governmental Preparatory Schools of Bale Zone. To accomplish this purpose, the study was employed a concurrent nested research design. A total of 86 individuals have participated in the study. Among them 70 teachers were included through simple random sampling technique. Additionally, 7 directors and supervisors and 9 woreda educational expertises' were included through census technique. Questionnaire and interview were the main instruments of data collection. The analysis of the quantitative data was carried out by using percent, mean, standard deviation and Pearson product correlation coefficient. Pearson product correlation coefficient results revealed that there was a significant and positive relationship between teachers' job satisfaction and commitment $(\mathrm{r}=.48, \mathrm{~N}=70)$, teachers', and directors, supervisors and woreda educational expertise's of teachers are respondents. Higher levels of teachers' job satisfaction were associated with higher levels commitment in the study area. Furthermore, teachers' high job satisfaction had positive effect on teachers' commitment, as opposite low job satisfaction had negative effect on teachers' commitment, preparation and students' learning outcomes, teacher retention and absenteeism. As the mean and standard deviation teachers', and directors, supervisors' and wereda Education office coordinators revealed that the level of teachers' job was dissatisfied and affected by salary and benefits, management system, work characteristics and load, advancement and promotion and interrelationship (mean= 2.48, std deviation=1.09). Based on the these findings, it can be recommended that, Woreda and Zone education Departments should give an opportunity of Educational training in regular program, provide necessary equipment and material on time, give fair incentives and different benefits for preparatory schools, making the School environment secular and provide the working conditions with refreshment facilities.
\end{abstract}

DOI: $10.7176 / \mathrm{JEP} / 11-10-01$

Publication date: April $30^{\text {th }} 2020$

\subsection{Introduction}

\subsection{Background of the study}

Education is a basic human right and a significant factor in the development of children, communities, and countries. Also it is known that improving educational performance takes high rank on the countrywide issue, with educators, curriculum developers and policymakers focusing on testing, accountability, curriculum reform, teacher quality, school choice, and related concerns. A high quality teaching staff is the basis of a successful school leadership system. In relation to these ideas, Sharma and Jyoti (2006) summarize, attracting and retaining high quality teacher is a primary requirement for an educational institution. Moreover, for the development of quality teachers one has to understand factors associated with it. Among these factors, job satisfaction is one of those important factors. Job satisfaction is a multi-faceted concept, composed of a range of factors related to a job. While Teachers' job satisfaction is a multifaceted phenomenon (Sharma and Jyoti 2006, Srivastava, Holan i\& Bajpai 2005) that is critical to turnover and commitment (Mathieu \&Zajac 1990), and school effectiveness.

Hongying, (2008) viewed, job satisfaction refers to the overall attitude and views of teachers toward their working atmospheres and profession. Also Zembylas, M., and Papanastasiou, E.(2006), supplement teacher job satisfaction as an important of the perceived relation between what one wants from teaching, and what one perceives teaching is offering to a teacher. So, teachers are the most important resources in a school. The provision of a high quality education system depends on high quality teachers Jyoti\& Sharma, (2009). A teacher is a classroom practitioner, the one who interprets educational philosophy and objectives into knowledge and skills. Hence, teachers play the most decisive position in influencing social and economic development of the students. They are expected to devote themselves professionally, with providing knowledge, skill and attitude.

Teachers, specifically, spend a great amount of time with their students in class, and hence they have a significant impact on student achievement (Correnti, Miller \& Rowan, 2002; Jyoti\& Sharma, 2009). To realize this, one of the important key to providing education in the schools is teachers. Moreover, teachers, like other employees have moral obligation for over all development of their country. On the way of doing that, they want 
to be professionally effective and satisfied on their job. As indicated by Jaiyeoba and Jibril (2008), satisfied and motivated teachers are important for any educational system. The success or failure of the education system depends mainly on satisfied teachers, but also on satisfied school managers and administrators.

Researchers, policymakers, and education leaders agree that teacher satisfaction is a critical factor that affects student achievement. Teachers' job satisfaction is one of the key factors in institutional changing aspects and is the most important part in terms of the effectiveness of an organization human resource is evaluated (Jyoti \& Sharma, 2009). Therefore, the understanding the effects of teachers' satisfaction on their commitment at the workplace is prominent for successful educational settings.

Accordingly Shann (2001) describes that teacher satisfaction has been shown to be a predictor of teacher retention, determinates of teacher commitment, and, in turn, a contributor to school effectiveness. Commitment refers to an individual's attraction and attachment to the work and the organization. It refers to the bonding of an individual to his group or organization, its goals and values or to his occupation and profession. It could manifest in terms of three ways i.e., affective, normative and continuance and each type of commitment ties the individual to the organization in different ways and will differently affect the manner in which the employee conducts $\mathrm{him} /$ herself in the workplace (Meyer et al, 2002). Fostering commitment among teachers is important because teachers', who are highly committed stay longer, perform better, actively involved in the work and engage in organizational citizenship behavior. In addition, the commitment and effectiveness of teachers depend on their motivation, morale and job satisfaction.

The availability of competent teachers with the required knowledge, skill and attitude is a key factor for providing of quality of education, yet lack of job satisfaction may affect the productivity of even those well qualified and highly skilled directly or indirectly through exhaustion, absenteeism, apathy and turnover, all of which can lead to a lack of work continuity. This implies that teacher job satisfaction and their commitment is an important phenomenon for generally all school teachers, their employers and students at large. For the success of any organization, committed and satisfied human resources are considered as the most important assets of an organization.

In contrast to this, teachers less satisfaction on their job makes them to reflect frustration in work environment. Their frustration will be manifested through different conditions. As Firestone and Rosenblum (1989) identified five important organizational factors which influence teacher commitment: sense of purpose about the work, mutual respect and affiliation, administrative support, and opportunities for decision- making. Each of these factors derives from the subjective relationship between the teacher and the principal of the school - reflecting as much the way a school leader is viewed by teachers as it does some objective degree of support, management, or control provided.

Generally, all schools will not be smoothly functional and cannot achieve their objectives and goals unless teachers are satisfied in their job. Hence, this study ware try to identify the effect of teachers' job satisfaction on their commitment in Bale Zone selected Governmental Preparatory Schools analyzing the issues, offering conclusions and providing specific recommendations based on the findings of the future study.

\subsection{Statement of the problem.}

The main purpose of any educational system is to producing the skilled manpower that helps for the dynamic management and leadership, political, institutional, social and economic development of the country. These will be achieved when the components of the educational systems are in a good situation. Among several components of the educational system, functional satisfied, committed and motivated teaching force in the system is crucial. If the teachers are not satisfied in their job, their moral would be poor and a lot of damage is happened to the skilled man power supply (Naylor, 1999). In this regard, Green (2000) has suggested three theoretical frame works to understand the job satisfaction at the work place: content or needs theories, process theories, and situational models of job satisfaction. All of these frameworks are useful to a greater or lesser extent to understand the job satisfaction of teachers. In relation to this idea, the social context of work is also likely to have a significant impact on a workers' attitude and behavior (Marks, 1994). If teachers' moral is diversely affected, it is not easy to expect optimal commitment in their profession. As West and Belington (2001:103) states', teachers are the most important resources available within the school, therefore, the pattern of and support for teachers' development were the most important determinant of the schools efficiently.

There are plenty of international, continental and local studies which have been conducted in the areas of teachers' job satisfaction and come up with different results. For instance, the result of the survey done in Botswana by Monyatsi (2012) indicates, "teachers are generally satisfied with their jobs" (p.219). There was also research studied in Tanzania by Ngimabudzi, F.W. (2009) with findings of Non-Government Secondary School teachers are more satisfied in their job than their colleagues in Government Secondary School . Furthermore, a research conducted on secondary school teachers in Taiwan comes up as teachers were satisfied with their job (Abdullah et.al, 2009). They conducted the study by comparing subjects with some variables: gender, qualification, level and age. 
According to Mwamwenda (1995), a lack of teacher job satisfaction results in frequent teacher absenteeism from school, aggressive behavior towards colleagues and learners, early exits from the profession, and psychological withdrawal from the work. All of these negative results lead to poor quality teaching.

Other studies showed that a lack of job satisfaction is often accompanied by feelings of gloom, despair, anger, resentment and futility (Pinder, 2008). Thus, a lack of job satisfaction has serious effects for the teacher, as well as for the educational system in which he or she is employed. In addition, it appears that one of the prime factors that affect the achievement of educational objectives of students is the scarcity of knowledgeable and committed teachers in schools with required quality and quantity. Absence of professionally skilled man power and lack of clear knowledge in school teaching systems are the major educational problems nowadays in schools which affect students' achievements (Hargreaves, 2004).

However, local studies were concerned; a few were conducted in relation to teachers' job satisfaction. According to Gedefaw (2012), teachers were significantly dissatisfied with most aspects of their work. The area of dissatisfaction teachers' work factors includes; salary, poor benefits and opportunities for promotion, the management style of the principals and the poor relationships teachers have with the principals and the parents. To support this idea, Desta (2014) also explains the Secondary School teachers' satisfaction and commitment on their job are low because the level of affective, continuance, and normative commitment. Hence, from the above studies and findings researcher feels that the preparatory schools teachers are not committed to their job because majority of teachers in the school expect external force to do their job, and poorly interested to achieve school goal and objectives.

Nonetheless, the above studies come with different findings in different countries; none of them were conducted on the Preparatory Schools level. Most of the time the researcher heard as preparatory Schools teachers complains their profession, dissatisfied with their job and poor commitment. So, these initiate the researcher to conduct research on the effect of teachers' job satisfaction on their commitment at Bale Zone selected Governmental Preparatory Schools. Therefore, the current research was different from the above and other studies in place and school level in order to fill the gap. Bearing this in mind, the study will try to answer the following research questions.

1. What is the level of job satisfaction of employees/teachers' in Bale Zone selected Governmental Preparatory Schools?

2. How employees' job satisfaction relates with their commitment in Bale Zone selected Governmental Preparatory Schools?

3. What is the effect of employees' job satisfaction on job commitment in Bale Zone selected Governmental Preparatory Schools?

\subsection{Objectives of the study}

\subsubsection{General Objective}

The general objective of this study was to investigate the effects of teachers' job satisfactions on their commitment in Bale Zone selected Governmental Preparatory Schools.

\subsubsection{Specific Objectives}

The specific objectives of this study were:

1. To assess the level of Teachers's satisfactions in Bale Zone selected Governmental Preparatory Schools.

2. To investigate the relations between job satisfaction and their commitment in Bale Zone selected Governmental Preparatory Schools.

3. To assess the effect of job satisfaction on employees commitment in Bale Zone selected Governmental Preparatory Schools.

\section{Methodology of the study}

\subsection{Description of the study area}

The site of study was at Bale Zone selected Governmental Preparatory Schools. Bale Zone is one of the largest zones in Oromia National Regional State with an area of $66,032.52 \mathrm{~km}^{2}$ which is located in the south and south eastern part of the state at the distance of $430 \mathrm{~km}$ from the capital city of Addis Ababa (Bale Zone culture and tourism office, 2013).

Geographically, Bale Zone is located between $5^{0} 22, \mathrm{~N}$ to $8^{0} 8, \mathrm{~N}$ and $38^{0} 52$, E to $42^{0} 4$, E. The study area was fallen within three Woredas of the Bale zone and two town Preparatory Schools, namely Dinsho, Agarfa, Oborra, Robe and Batu Preparatory Schools.t

\subsection{The research design}

Descriptive research design was employed to determine the relationship between the dependent and the independent variables and to establish any association between these variables. According to Mugenda \& Mugenda (2003), descriptive survey design helped a researcher to gather, summarize, present and interpret 
information for the purpose of clarification. Statistical instrument to be used for the research analysis was mainly descriptive statistics, specifically mean and standard deviation. The researcher was employ the survey strategy for the study. This strategy is proposed because it allows the collection of a large amount of data from a sizable population in an economical manner. Saunders et al. (2009), recommend this strategy because the method allows researchers to collect quantitative data which can be analyzed quantitatively using inferential statistics. The method is also perceived as authoritative by people in general and is both comparatively easy to explain and to understand.

A mixed approach is a procedure for collecting, analyzing, and "mixing" both quantitative and qualitative methods in a single study or a series of studies to understand a research problem (Creswell, 2012). The basic assumption is that the uses of both quantitative and qualitative methods, in combination, provided a better understanding of the research problem and question than either method by itself. In mixed methods research, investigator used both quantitative and qualitative data because they worked to provide the best understanding of the research problem.

In this research the quantitative approaches embed the qualitative one to descriptive the effects of teachers' job satisfaction on their commitment in the study area. Therefore, this concurrent nested approach is more convenient to get in-depth data on the effect of teachers' job satisfaction on commitment in Bale Zone selected Governmental Preparatory Schools.

\subsection{Research Approach}

Approach is a style of conducting a research work, which is determined by the nature of the problem. Thus, both quantitative and qualitative approaches were employed to investigate the effects of teachers' job satisfaction on their commitment in Bale Zone selected Governmental Preparatory School.

\subsection{Sources of data}

The sources of data in this study both primary and secondary sources. Primary data was obtained from woreda education office expertise, teachers, principals and supervisors. Because, these responsible bodies who are currently leading the teaching learning operations can reflect teachers job satisfaction and their commitment conditions from their practical experiences rather than other bodies. Whereas information was also collected from document review of statistical record and written as sources of information from secondary sources.

\subsection{Target population}

According to Opie (2007), population is the entire cohort of subjects that a researcher is interested in. For the purpose of this study, the target population of this research is all teachers in 5 selected Governmental Preparatory Schools, schools Directors and Supervisors Worada Educational coordinators and expertise. The number of the population is listed in the following table.

Table1: Distribution of the Population

\begin{tabular}{|c|c|c|c|c|c|c|c|}
\hline No_ & Respondents & 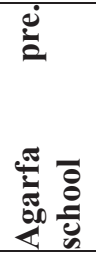 & 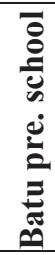 & 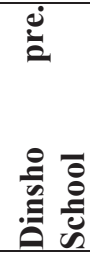 & $\begin{array}{l}\stackrel{0}{0} \\
\text { ב }\end{array}$ & 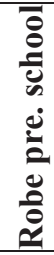 & 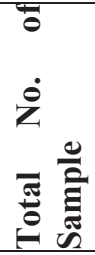 \\
\hline 1 & Teachers & 25 & 34 & 20 & 18 & 31 & 128 \\
\hline 2 & Directors and Supervisors & 3 & 3 & 2 & 2 & 3 & 13 \\
\hline 3 & $\begin{array}{l}\text { Worada Educational coordinators } \\
\text { and expertise }\end{array}$ & 3 & 4 & 3 & 3 & 4 & 17 \\
\hline & Total & 31 & 41 & 25 & 23 & 38 & 158 \\
\hline
\end{tabular}

\subsection{Sample size and sampling techniques}

Fraenkel and Wallen (2000) define a sample as a smaller group of subjects drawn from the population in which a researcher is interested in gaining information and drawing conclusions. It involves a process where a researcher extracts from a population, a number of individuals so as to represent adequately, a larger group. According to Yamane (1967) simplified formula for calculation of sample size from a population for a 95\% confidence level and $5 \%$ deviation factor, the size of the sample given as $n=\frac{N}{1+N e^{2}}$ where $\mathrm{n}$ is the size of sampling, $\mathrm{N}$ is size of population and $\mathbf{e}$ is deviation of sampling. Therefore, the researcher want a sample of size $n=113$ which calculated by used the above formula from the target population to be drawn in the study $(N=158)$.As well as C.R. Kothari (1990), to allocate the sample size of each Stratum, that is, if $P i$ represents the proportion of 
population included in stratum $i$ means, $P_{i}=\frac{N_{i}}{n}$, where $\mathrm{N}_{\mathrm{i}}$ is the population size of stratum and $n$ represents the total sample Size, the number of elements selected from stratum $i$ is $\boldsymbol{n}$. Pi . For instance, from total numbers of teachers in the selected school, $128(100 \%)$ out it $92(72 \%)$ teachers will randomly selected on the proportionality of numbers on the base that the researcher assumes they are relevant source of data for the study. Correspondingly, 12(71\%) school supervisors and directors were included by using census because as the researcher believes they are relevant bodies to provide appropriate information for the study due to their high intimacy with teachers in their day to day activities. Besides, 9(69\%) woreda education coordinators and expertise will be selected by using census for detail information in target areas of studies. The researcher believes that they are responsible bodies to what extent teachers are satisfied and committed and they have ample data from selected schools. The sample size for teacher respondents from schools will be determined by using their proportionality of numbers in the school. This is for the sampling to be representative of the population, and possible to involve respondents from all sample schools in equal percentage. Finally, the main reason for selecting the five schools is as these schools experienced teachers who can give appropriate information about the problem at hand. Not only but also, newly constructed Preparatory School was included with their fresh teachers. Generally, the total respondent of this study will be 113 .

Table 2: Sample school included in the study with their respective level and number of teachers:

\begin{tabular}{|l|l|l|l|l|}
\hline No_ & Participants & Population & Sample $\left(\mathrm{n}_{\mathrm{i}}=\mathrm{np}_{\mathrm{i}}\right)$ & Percentage \\
\hline 1 & Teachers & 128 & 92 & $72 \%$ \\
\hline 2 & Directors and Supervisors & 13 & 9 & $69 \%$ \\
\hline 3 & Worada Educational coordinators and expertise & 17 & 12 & $71 \%$ \\
\hline & Total & 158 & 113 & $71.51 \%$ \\
\hline
\end{tabular}

Based on this, the population, samples and sampling techniques will be summarized as follows:

Table 3: Samples and sampling techniques

\begin{tabular}{|l|l|l|l|l|}
\hline No. & Participants & Total population & Samples & Sampling techniques \\
\hline 1 & Teachers & 128 & 92 & $\begin{array}{l}\text { Simple random sampling } \\
\text { (lottery system) }\end{array}$ \\
\hline 3 & Director and Supervisors & 13 & 9 & Census \\
\hline 5 & $\begin{array}{l}\text { Worada Educational coordinators and } \\
\text { expertise } \\
\text { Total }\end{array}$ & 17 & 12 & Census \\
\hline
\end{tabular}

\subsection{Instrument of data collection}

Data collection is a process that a researcher used to gathers data from various sources of information proportional to the research plan to prove some phenomena. The use of multiple techniques were employed as a means of crosschecking the authenticity of data from single source, enhancing their validity and reliability and increase in-depth and understanding of the phenomenon. This enhances and increases the researcher's confidence on the credibility of the results.

Research instruments refer to the technique or methodology used in collection of data (Best and Kahn, 2011). Therefore, in this study the researcher used three research instruments namely; questionnaires, interview and document analysis for collecting data from the respondents.

\subsubsection{Document Analysis}

According to Omari (2008) documentary analysis includes the review and analysing accurate information recorded or published regarding the area of study. For the purpose of this research, documents are official recorded materials that give information about phenomena that can be used as evidence or proof in the process of investigation of specific information or topic. The researcher used documentary analysis to collect secondary data and go the opportunity to see the statistical data of turnover, absenteeism from school, tutorial providing rates for different level students', job satisfaction leaving rates of teachers' and related issues from Preparatory School and woreda education offices.

\subsubsection{Questionnaires}

A questionnaire is a set of questions that respondents are asked as a way of getting information about what people think or do generally (Shovel, 2007). A questionnaire was designed and tailored to the study's objectives. It is a research instrument consisting of a list of questions that a number of people are asked so that information can be collected about something. The questionnaires which were used in this study are two types namely, open ended and close ended. Open ended questionnaire items refer to the questions which give the respondents complete freedom in responding, while closed ended questionnaire items refer to questions which are accompanied by a list of all possible alternatives from which respondents select the answer that best describes the situation. Therefore, both closed and open items were employed to collect quantitative and qualitative data 
from teachers, directors and school supervisors. This is because questionnaire is convenient to conduct survey and to acquire necessary information from large number of study subject within a short period of time.

The questionnaire was prepared in English language, because the researcher believed that all of the sample teachers can have the necessary skills to read and understand the concepts that were incorporated. To make the data collection procedure smart and cleared from confusions, the researcher was properly orient respondents about the procedures. Furthermore, few open ended type of questions were used in order to give opportunity to the respondents to express their feelings, perceptions, problems and intentions related to teacher's job satisfaction and commitment.

\subsubsection{Interviews}

Thunguet al., (2008), defines an interview as a private meeting in which a researcher asks an interviewee questions in order to gather information. Interviews are interactive, less formal and less uniform compared to questionnaires. The researcher used this method simply because it was believed to provide direct answers. In this case, unstructured interview was employed to get the detail information from school leader employees and woreda education office expertise, directors and supervisors development coordinators was included in the study because, they are more related to the problem. Thus, the purpose of the interview was to collect more supplementary data by providing them the opportunity to their opinion, feeling freely, and allow the researcher to use the idea that contrast with the questionnaires or to triangulate the questionnaire response.

\subsection{Procedure of data collection}

To answer the research questions raised, the researcher would have to go through series of data gathering procedures. The researcher receives the authorized official cooperation letters from Madda Walabu University and Education Departments of selected woredas, for ethical clearance. The researcher introduced the objectives and a purpose of the study for participants. Then, gather trustworthy data by from respondents' questionnaires, and interviews. The researcher administered questionnaires to the respondents. The interviews were administered for 21 woreda education coordinators and expertise, directors and supervisors. Finally, the researcher collected all the data from the participants to resume the research work.

\subsection{Method of data processing and analysis}

According to Kothari (2011), Processing of data means editing, coding, classification and tabulation whereas analysis refers to computation of certain measures along with searching for patterns of relationship that exists among data-group. The researcher was process data obtained from interview by carrying out manual editing, coding, classifying and tabulating. Data obtained from documentary review was recorded in tables or described qualitatively. The collected data were analyzed both quantitatively and qualitatively. The analysis of the data was based on the responses that were collected through questionnaires, interviews, and document analysis.

The qualitative data collected from different sources was summarized, categorized and coded to suit for analysis. The data collected from teachers, school facilitators, director, and supervisors through questionnaire (the quantitative one) was processed and analyzed using Statistical Package for Social Science (SPSS) version 20 likes tools percentage, mean, standard deviation, linear regression and Pearson product correlation coefficient used to analyze the data. The output of the data was presented appropriately depending on the respondents' response. The end result was presented in written form and in the form of table. This was made by descriptive statistics that was appropriately used for the understanding the main characteristics of the research problems. On the other hand, the data which obtained from open-ended items, interviews and document analysis was analyzed qualitatively by transcribing respondent's ideas and views through narrations, descriptions and discussions. Thus, analysis of data was easier through transcribing and coding data. Finally data presentation, analysis, and interpretation, and conclusions and recommendations were drawn based on the analyzed data.

\subsection{Validity and reliability checks}

Validity is the extent to which the measuring instrument (e.g., a questionnaire) we are using essentially measures the characteristic or dimension we intend to measure (Leedy \& Ormrod, 2001:98). To achieve the validity in the instruments of data collection, the instruments which initially prepared in English language, and checked by advisor in order to comment the extent to which the items are appropriate in securing relevant information to the study. As discussed above, all the items that develop to address the research questions under investigation made to maintain validity of the instruments of the study those elements was contained in the basic research questions. That is, the items construct was in line with the answer to the research questions. Content validity addressed to what extent the appropriate content is representing in questionnaires and interview guide items. The researcher will make change or replace the construction of some items in the questionnaires and interview guide based on the comment and feedback received from advisor.

According to Cohen (2007:146), Reliability is the consistency, dependability and explicability of the measuring instrument over time, and with the same respondents. It is the extent to which the measuring 
instrument yields consistent and accurate results when the characteristic being measured remains constant. One means of increasing the reliability of the instrument is the inclusion of more items in the questionnaire. Furthermore, the main issue of reliability is addressing the consistency of the instruments in relation to what they intend to measure. Accordingly, the basic idea of reliability is summarized up by the word consistency. The researcher adopt different standardized measurements scale of teachers' job satisfaction and commitment.

\subsection{Ethical consideration}

Ethical consideration plays an important role during data collection time. Researcher was aware and follows the ethical consideration related to the studies. Furthermore, the first page of the questionnaires will display an opening introductory letter that requesting the respondents' cooperation to provide the required information for the study. They are assured that the information they provide was keep confidential. To data collections from study participants, all potential study participants informed about the procedure that was used in the study; the researcher explains the objectives and significance of the study to the respondents. To ensure this, the researcher was removing the respondents' information that requires identification of names and other identity. During the data collection and any activities that matter to the research, the researcher was made positive interaction with respondents.

\section{Data Presentation, Analysis and Discussion 3.1 Introduction}

This chapter is intended to present, analyse and discuss the data collected in with respect to the research objectives and their respective questions used during the study. In the study, different groups of people were included to get the necessary information. The groups that were included in the study were teachers, directors, and supervisor, and woreda educational expertise of teachers. Analysis and interpretation of the data gathered by different instruments, mainly questionnaire and unstructured interview and the summary of the quantitative data has been presented by the use of tables and various statistical tools. Similarly, the qualitative data were organized according to the themes, analyzed and used to strengthen or to elaborate quantitative one. Because the research design is concurrent nested mixed research design, thus the qualitative data is used to support the result obtained from the interpretation of the quantitative data.

The aim of this study was to assess the effect of teachers' job satisfaction on their commitment at selected governmental Preparatory Schools in Bale Zone. The first part presents the background information of the respondents followed by descriptive and inferential statistics. To maintain ethical issues the study has not included the names of the respondents because the researcher ensured confidentiality of the information provided by the respondents.

The study was guided by the following research objectives

1. To assess the level of Teachers' satisfactions in Bale Zone selected Governmental Preparatory Schools.

2. To investigate the relations between job satisfaction and their commitment in Bale Zone selected Governmental Preparatory Schools.

3. To assess the effect of job satisfaction on employees commitment in Bale Zone selected Governmental Preparatory Schools.

In this study, the main sources of data were 5 selected governmental Preparatory Schools directors, 4 supervisors, 92 teachers, and 12 woreda educational expertise's of teachers, directors, and supervisors developments coordinators'. A total of 113 questionnaires were distributed but properly filled and returned were 86(76\%). From these respondents 70 (76\%) were teachers. Among 21 interview respondents 7(77.78\%) were directors and supervisors and 9(75\%) woreda educational expertise's of teachers, directors, and supervisors developments coordinators' have properly participated and gave necessary information on the issue under investigation.

In general 113 out of 86 or $(76 \%)$ of respondents participated and gave necessary information on the issue rose through questionnaire and unstructured interview were participated. Therefore, the total response rate is sufficient and safe to analyze and interpret the data.

The overall results of the issue investigated as well as respondent's personal background or profiles are presented below.

\subsection{Analysis of the Background Respondent's Data}

Table 4.1 illustrates the respondents' biographical information as determined by questions 1 to 4 of the questionnaire. The total number of respondents was 70 . 
Table 4 the biographical data of the teachers

\begin{tabular}{|c|c|c|c|}
\hline \multicolumn{2}{|l|}{ Variable } & frequency & Percentage \\
\hline \multirow{3}{*}{ Sex } & Male & 57 & 81.4 \\
\hline & Female & 13 & 18.6 \\
\hline & Total & 70 & 100.0 \\
\hline \multirow{6}{*}{ Age } & Below 25 years & 1 & 1.4 \\
\hline & $26-30$ years & 28 & 40.0 \\
\hline & $31-35$ years & 13 & 18.6 \\
\hline & $36-40$ years & 10 & 14.3 \\
\hline & Above 40 years & 18 & 25.7 \\
\hline & Total & 70 & 100.0 \\
\hline \multirow{4}{*}{ Marital status } & Married & 56 & 80.0 \\
\hline & Single & 11 & 15.7 \\
\hline & Separated & 3 & 4.3 \\
\hline & Total & 70 & 100.0 \\
\hline \multirow{3}{*}{$\begin{array}{l}\text { Academic } \\
\text { qualification }\end{array}$} & Degree & 39 & 55.7 \\
\hline & Masters & 31 & 44.3 \\
\hline & Total & 70 & 100.0 \\
\hline \multirow{7}{*}{ Service year } & Below 5 years & 3 & 4.3 \\
\hline & $6-8$ years & 7 & 10.0 \\
\hline & $9-11$ years & 18 & 25.7 \\
\hline & $12-14$ years & 13 & 18.6 \\
\hline & $15-17$ years & 9 & 12.9 \\
\hline & More than 18 years & 20 & 28.6 \\
\hline & Total & 70 & 100.0 \\
\hline
\end{tabular}

Table 4 illustrates that out of 70 teachers, males were in the majority $(\mathrm{N}=57,81.4 \%)$, and females made up the rest $(\mathrm{N}=13,18.6 \%)$. It was evident that the population was mainly composed of male teachers. The frequency distribution of the respondents by age showed that most of them $(\mathrm{N}=28,40 \%)$ were in the age category 26 to 30 years. This group was also the youngest age group among them $(\mathrm{N}=56,80 \%)$ were married, $(\mathrm{N}=11,15.7 \%)$ were single and $(3,4.3 \%)$ were separated. The respondents who belonged to the age category above 40 years constituted the second largest group of respondents $(\mathrm{N}=18,25.7 \%)$. The respondents who were in the age of 31 to 35 and 36 to 40 years constituted $(\mathrm{N}=13,18.6 \%)$ and $(\mathrm{N}=10,14.3 \%)$ of the sample respectively, while $1.4 \%$ of the sample belonged to the age of below 25 years. This shows that the group is predominantly young.

Table 4 also indicates that the largest group $(\mathrm{N}=20,28.6 \%)$ of the respondents had more than 18 years experience as a teacher. Moreover, about $(\mathrm{N}=18,25.7 \%)$ of the respondents had 9 to 11 years' teaching experience. Besides, $(\mathrm{N}=13,18.6 \%)$ and $(\mathrm{N}=9,12.9 \%)$ of the respondents had 12 to 14 and 15 to 17 years teaching experience. This showed that most of the respondents were relatively experienced teachers.

The table above also shows that the most academic qualification of the respondents was a bachelor's degree $(\mathrm{N}=39,55.7 \%)$. others $(\mathrm{N}=31,44.3 \%)$ of the respondents hold masters' degrees. This result shows that, the teachers in the selected preparatory schools hold a first degree.

\subsection{Results of the Quantitative Data}

The first objective aimed to assess the level of teachers/employee job satisfaction whereby teachers were asked to rate their satisfaction as satisfied and dissatisfied as for question 1 , to facilitate clarity of interpretation, the five questionnaire response categories (strongly disagree $=1$ disagree $=2$, neutral $=3$, agree $=4$ and strongly agree $=5$ ) were divided into two categories, namely disagree and agree. The findings from the respondent of the five selected preparatory schools were summarized.

\subsubsection{Research question 1}

What is the level of job satisfaction of employee/teachers in preparatory schools under the following condition, namely salary and benefits, management, work characteristics, and interpersonal relationships?

As it was discussed in the literature review section of the study, it was decided to examine separately the majority factor of job satisfaction under external and internal benefits are the salary and benefits, management, advancement and promotion, work characteristics, and interpersonal relationships. The analysis of each of the five factors is as follows. 
Table 5 the mean and standard deviations satisfaction ratings of the four 'work' factors.

\begin{tabular}{|l|l|l|c|}
\hline Factors & N & Mean & SD \\
\hline salary and benefits & 70 & $\mathbf{1 . 7 7}$ & $\mathbf{0 . 8 4}$ \\
\hline Management & 70 & $\mathbf{2 . 2 8}$ & $\mathbf{1 . 0 2}$ \\
\hline advancement and promotion & 70 & $\mathbf{2 . 1 7}$ & $\mathbf{1 . 1 4}$ \\
\hline work characteristics & 70 & $\mathbf{2 . 8 0}$ & $\mathbf{1 . 2 5}$ \\
\hline interpersonal relationships & 70 & 3.04 & 1.23 \\
\hline Overall score & & 2.41 & $\mathbf{1 . 0 9}$ \\
\hline
\end{tabular}

Scales; $\leq 1.49=$ Strongly Disagree, $1.5-2.49=$ Disagree, 2.5-3.49=Neutral/Undecided, 3.5-4.49=Agree, $\geq$ $4.5=$ strongly agree .

The following graph also shows the overall levels of teachers' job satisfaction on main factors.

Graph 1 overall teachers' teachers' job satisfaction

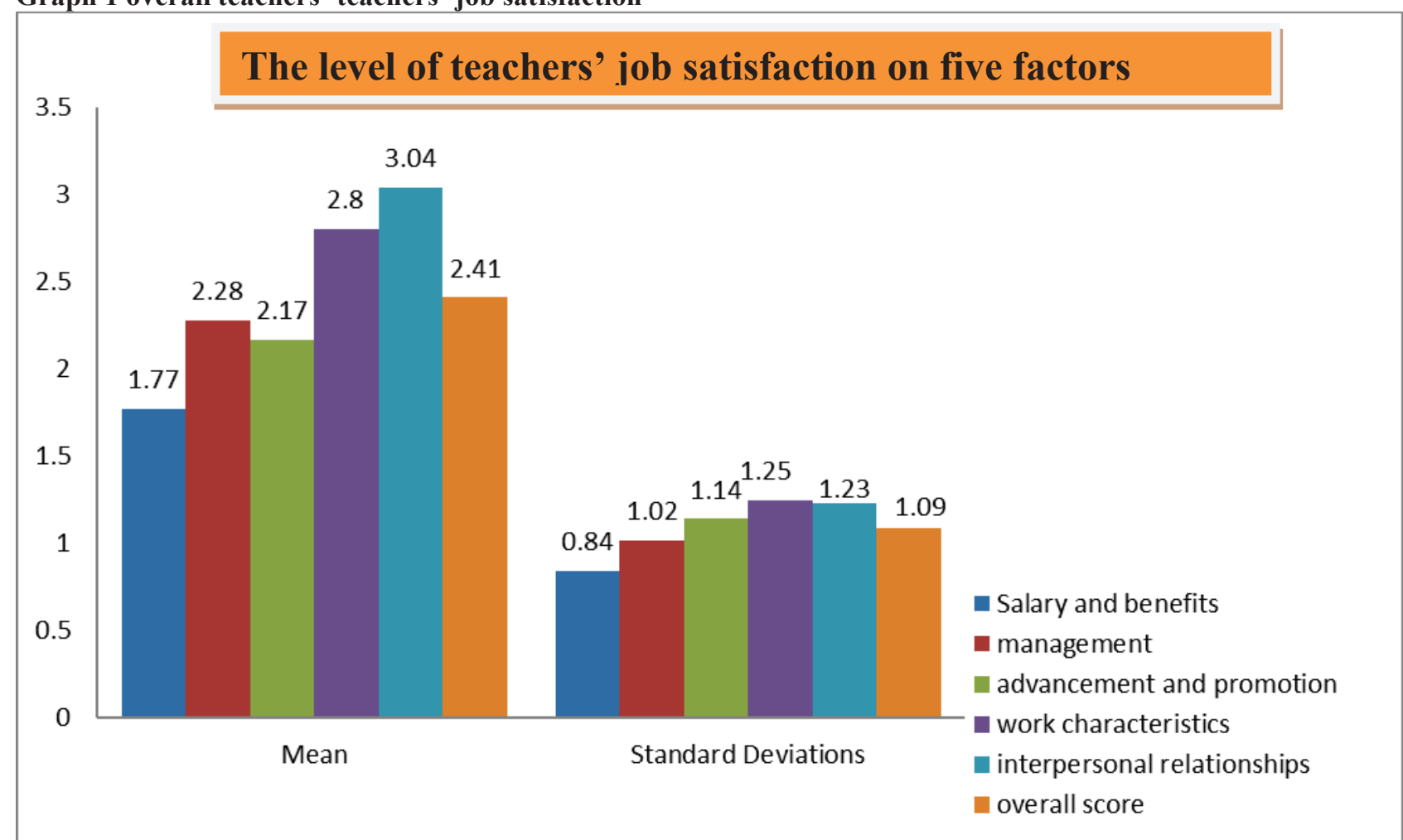

Scales; $\leq 1.49=$ Strongly Disagree,$\quad 1.5-2.49=$ Disagree,$\quad 2.5-3.49=$ Neutral/Undecided, $3.5-4.49=$ Agree, $\geq 4.5=$ strongly agree .

Table 5 shows that the lowest mean satisfaction rating was for the salary and benefits factor. The mean value of this factor was 1.77 , a value obtained by aggregating the mean values of each of the statements of Tables 6,7 , and 8 that follow, and then dividing this value by the total number of items constituting the factor 'salary and benefits' - in this case of 8 items were used. It can clearly be seen that the teachers' experience of this factor was towards the disagreement or dissatisfaction end of the continuum.

Table 5 also shows the mean satisfaction rating of the management factor. This aspect focused on administrative support, school management and leadership, and recognition. The mean value of this factor was 2.28 , thus indicating that; in general, teachers were relatively disagree/dissatisfied level with this aspect of their work.

Advancement and promotion factor includes the growth and development, job security and upward status, a mean factor of 2.17 indicated that the teachers were dissatisfied level with this side of advancement and promotion

Work characteristics encompass workload, the nature of the work and responsibility. A mean of 2.8, as indicated that teachers were also relatively undecided/neutral level with this aspect of their work and this is the highest mean of all the factors.

Table 5 indicates the mean satisfaction rating of the interpersonal relationships factor. This factor includes the relationship of teachers with their principal, colleagues, students and parents. A mean factor of 3.04 indicated that the teachers were slightly undecided/neutral level with interpersonal relationships. Finally, it was illustrated that, with a standard deviation of all factors indicated the level of strongly dissatisfied 
In the next sections, the teacher's responses on the individual items of the questionnaire and interview of directors, supervisors and Woreda educational Coordinators were presented.

\subsubsection{Factor 1: Salary and fringe benefits}

The frequency, means and standard deviation of the teachers' responses indicate whether they were satisfied or dissatisfied with their salaries (Table 6), their Benefits

Table 6 The teachers' views on their salaries and benefits

\begin{tabular}{|c|c|c|c|}
\hline Statements/items & $\mathrm{N}$ & Mean & $\begin{array}{l}\text { Std. } \\
\text { Deviation }\end{array}$ \\
\hline I am happy with the types of allowances given & 70 & 1.89 & .941 \\
\hline As a teacher I enjoy many benefits & 70 & 1.69 & .753 \\
\hline I am satisfied with my job. & 70 & 2.20 & 1.162 \\
\hline $\begin{array}{l}\text { I am satisfied with autonomy I have in making decisions about my daily } \\
\text { tasks. }\end{array}$ & 70 & 1.89 & .941 \\
\hline My salary is appropriate for my experience and enhances my status & 70 & 1.43 & .650 \\
\hline My salary is equal to the effort I put in my job & 70 & 1.51 & .676 \\
\hline The monthly salary is sufficient to meet all my important expenses. & 70 & 1.37 & .543 \\
\hline I feel comfortable with my future incomes & 70 & 2.21 & 1.062 \\
\hline Overall score & & 1.77 & 0.84 \\
\hline
\end{tabular}

$3.5-4.49=$ Agree,$\quad \geq 4.5=$ strongly agree .

The results in Table 6 showed that the teacher respondents disagreed/dissatisfied with all of the eight (8) statements. Thus, the data tended to reflect a pattern of teacher dissatisfaction as far as salary is concerned. In addition, a variable mean of 1.37 and 1.43 indicated that the teachers were very dissatisfied with this aspect of their work. The highest area of dissatisfaction or disagreement had to do with the appropriateness of their salaries to their experience, and the overall satisfaction level of the teachers' salaries followed by the factor whether the monthly salary the teachers received covered all their basic needs and whether their salary compared well with their academic qualifications.

The second area of dissatisfaction was related to whether their salary enhanced the status they had in the community, the comparison between teachers' salaries and the effort needed for the job, and whether the monthly salary the teachers received kept them in their jobs.

Table 6 also showed the means of each of the teachers' responses to the statements that focused on benefits. A variable mean of 1.69 indicated that the teachers were dissatisfied with the benefits they received. Furthermore, the respondents reported their disagreement/dissatisfied with the statement that they enjoyed many benefits. Similarly, the majority of the teacher respondents were unhappy with the types of allowances given to them. Approximately the majority of the respondents expressed their dissatisfaction with the overall salaries and benefits.

The woreda educational coordinators, directors and supervisors interview result also indicates that:

The teachers' benefits and incentive were inappropriate for extra work, and in school meeting, cluster teachers' meeting teachers' lack refreshment this lead teachers' dislike their profession. Therefore, lack sufficient incentive and others benefits for their additional work influence Teachers' level of satisfaction in job and may be limits level effort on the work. According to Ahuja and Shukla (2007), when incentives is offered for meeting specific goals, the employee is likely to expend more energy and effort into the job and thereafter the incentive will be given to the employee as a reward when the goal is met.

\subsubsection{Factor 2: Management}

The means and Standard Deviation of the teachers' responses indicated their satisfaction or dissatisfaction with management. This included the administrative support they received, school management and leadership and the recognition they received in the following table7.

Table 7 The teachers' views on school management and leadership

\begin{tabular}{|c|c|c|c|}
\hline Statements/items & $\mathrm{N}$ & Mean & $\begin{array}{l}\text { Std. } \\
\text { Dev. }\end{array}$ \\
\hline $\begin{array}{l}\text { I am happy with administrative support at school and the way teachers are } \\
\text { evaluated }\end{array}$ & 70 & 1.37 & .516 \\
\hline School administration supports good teacher-student relationships & 70 & 2.40 & 1.109 \\
\hline I am satisfied with care I receive from my immediate supervisor(s). & 70 & 3.11 & 1.198 \\
\hline I am pleased with the leadership style of the school director(s) & 70 & 1.90 & 1.092 \\
\hline My school leader values me as a teacher & 70 & 2.90 & 1.206 \\
\hline Overall score & & 2.28 & 1.02 \\
\hline
\end{tabular}

Scales; $\quad \leq 1.49=$ Strongly Disagree, $\quad 1.5-2.49=$ Disagree,$\quad 2.5-3.49=$ Neutral/Undecided, $3.5-4.49=$ 
Agree, $\quad \geq 4.5=$ strongly agree.

Table 7 presents the teachers' views on the five statements constituting the management and school leadership support variable. This table depicts that most of the respondents were dissatisfied with each of the four statements and undecided with one item. Thus, it seems that teachers were dissatisfied with the school administration practices. The variable mean of 1.37 also confirms the teachers' negative means very disagreement with regarding the support provided by their school administrators and the ways they were evaluated. In addition, the mean of 2.4 of the teacher respondents reported having dissatisfaction with the support provided the relation with respect to student disciplinary problems and the fairness of the school administration's evaluation system to evaluate the teachers' work. The school administration has influence on the teachers' satisfaction levels. Not more than half of the respondents reported there were undecided with school leaders' value for teachers at school and with the care they receive from supervisors. In addition, the mean 1.9 of the respondents indicated that the leadership style practiced by their principals did not enhance the teachers' satisfaction.

Over all table 7 indicates that most of the respondents were dissatisfied with management and leadership. This was also evident from the variable average mean of 2.28 . Specifically, more than $60 \%$ of the teacher respondents were dissatisfied with the respect they received from their schools administrations and leaders and the recognition they received from their immediate supervisors. The woreda educational coordinators, directors and supervisors interview result on also indicates and support this idea.

The presence of clear school based policy is satisfied majority teachers' but attitude, skills and knowledge gaps of principals, and school management and their poorly implementation of policy and administration in the school reduced satisfaction teachers' and also the practice of supervision in the school is insufficient to enhance teachers' job satisfaction on their job as in the implementation timely supervision for teachers' in both internal and external was ineffective. This show that the principals, and school management attitude, skill and knowledge gaps in implementation of school policy and their administration influence teachers' job satisfaction on the job. This indicates insufficient supervision of teachers' reduced effectiveness of performance of teachers' and influences teachers' level job satisfaction on the job. Therefore, effective supervision of teachers is important for successfully implementation of school goal and objectives.

\subsubsection{Factor 3: advancement and promotion}

The means and standard deviation of the teachers' responses indicate whether they were satisfied or dissatisfied with their opportunities for advancement and promotion (Table 8)

Table 8 the teachers' views on advancement and promotion

\begin{tabular}{|c|c|c|c|}
\hline Statements/items & $\mathrm{N}$ & Mean & $\begin{array}{l}\text { Std. } \\
\text { Deviation }\end{array}$ \\
\hline I feel comfortable with rewards I get for doing a good job in the school. & 70 & 2.00 & 1.077 \\
\hline I am comfortable with the promotion opportunities available to me & 70 & 2.04 & 1.273 \\
\hline The major satisfaction in my life comes from my job. & 70 & 2.03 & 1.251 \\
\hline $\begin{array}{l}\text { I feel satisfied with opportunities for training and professional development } \\
\text { available. }\end{array}$ & 70 & 2.16 & 1.020 \\
\hline $\begin{array}{l}\text { I am satisfied with opportunities to attend seminars within and outside the } \\
\text { school. }\end{array}$ & 70 & 2.21 & 1.080 \\
\hline Teaching provides me with opportunity to use all my skills. & 70 & 2.46 & 1.086 \\
\hline The promotion process and procedure used by my employer are fair. & 70 & 2.40 & 1.128 \\
\hline I have many opportunities for professional advancement & 70 & 2.11 & 1.186 \\
\hline Overall score & & 2.17 & 1.14 \\
\hline
\end{tabular}

Scales; $\quad \leq 1.49=$ Strongly Disagree,$\quad 1.5-2.49=$ Disagree,$\quad 2.5-3.49=$ Neutral/Undecided, $3.5-4.49=$ Agree, $\geq 4.5=$ strongly agree.

According to Table 8, the teachers held negative views of the opportunities they had for advancement and promotion. This was also evident from a variable average mean of 2.17 which indicated that the teachers were dissatisfied or disagreed with their advancement and promotion at the most items.

The woreda educational coordinators, directors and supervisors interview result on also indicates that:

Some teachers were satisfied with opportunity to use their skill and knowledge in the job and some of them were not satisfied due to lack of equipment and necessary material to use their skill and knowledge in practice in the school. Mass of fresh teachers was not interested to continue with teaching profession but, most of experienced teachers prefer to continue with teaching professions. The interview results revealed that trainings on various issues are given rarely due to a number of limitations such as budget, and teachers are not interested to be free to participate with issues organized by Woreda experts. Experiences sharing with model school and within schools are low, furthers education opportunity for first degree holders to second degree (MA/MSc) were also in regular programs is limited. 
In addition to this, data from document analysis show, even if most of teachers as well as preparatory schools have training and development plan within school level in the form of Continuous Professional Development (CPD) but, its implementation was not effective. Simply teachers and schools prepared their plan for the matter of planning, but not facilitate and monitor its implementation. The teachers' have little opportunity for training, experience sharing with other model schools, and professional development or advancement. Therefore, provision of job related training and development, experience sharing and workshop enhance academic performance of teachers and able to give better results. As Saeed and Asghar (2012), pinpoint training and development improves the motivation and satisfaction level of employees, increase their skill and knowledge, and also expands the intellect on overall personality of the employee.

\subsubsection{Factor 4: Work characteristics}

Work characteristics included workload, work itself, and their responsibilities at work are presented in Table 9.

Table 9 the teachers' views on their workload

\begin{tabular}{|l|l|l|l|}
\hline Statements/items & $\mathrm{N}$ & Mean & Std .Deviation \\
\hline I am satisfied with my workload within my department & 70 & 3.60 & 1.184 \\
\hline I am happy with my work hours & 70 & 3.73 & 1.250 \\
\hline I am happy with the type of work I do as a teacher & 70 & 3.43 & 1.347 \\
\hline I have the opportunity to use my skills at school & 70 & 2.41 & 1.161 \\
\hline Teaching is a challenging job to me. & 70 & 2.77 & 1.157 \\
\hline I enjoy much freedom in my place of work. & 70 & 2.80 & 1.336 \\
\hline I am satisfied with the amount of freedom I have in decision-making & 70 & 2.01 & 1.222 \\
\hline I feel satisfied with the recognition I have in the community. & 70 & 2.37 & 1.265 \\
\hline $\begin{array}{l}\text { I am comfortable with the geographical location (work environment) of the } \\
\text { school in which I teach. }\end{array}$ & 70 & 2.39 & 1.266 \\
\hline I would not like to be transferred to another school. & 70 & 2.63 & 1.321 \\
\hline I am not intending to change my profession. & 70 & 2.73 & 1.262 \\
\hline Overall score & & $\mathbf{2 . 8 0}$ & $\mathbf{1 . 2 5}$ \\
\hline
\end{tabular}

Scales; $\leq 1.49=$ Strongly Disagree, $1.5-2.49=$ Disagree, $\quad 2.5-3.49=$ Neutral/Undecided, $3.5-4.49=$ Agree, $\geq 4.5=$ strongly agree.

According to Table 9, the mean satisfaction of respondents on the work itself (mean=3.6) variable fell in the satisfied range. The variable mean of 3.73 also indicated that the teachers were on average of satisfied with this aspect of the work itself. The item in this group that met with negativity was that the opportunity they had to use their own skills at school and the cooperation of receive from their workmates and work environment of the school in which they teach disagreed/dissatisfied range.

Moreover, it is evident that the teachers were particularly dissatisfied with the freedom they had in decisionmaking, with mean of 2.01 reporting to be dissatisfied. Overall it is showed that the teachers' perceptions of their responsibilities at work and the work itself together indicated that the teachers were undecided levels with the mean of 2.80. This shows that large numbers of teachers' were not decided on the practices of transfers rates within Zone and Woreda. Besides that, the woreda educational coordinators, directors and supervisors interview result also indicates that:

The school environment is not fully satisfactory to enhance teachers' job satisfaction, because preparatory schools lack necessary school facilities and equipments due to budget problems. Thus, poor working conditions in the school block the teachers' access to do various works that support the teaching learning process. Mass of teachers expect command from the school principal, department heads or other concerned staff members to do their work but, few teachers were perform their task without expectation of their boss. It indicates the low initiation of teachers in performing their task without external pressure.

Therefore, this problem has an effect on reducing the teachers' level of job satisfaction, and this affect the students' academic achievement as well as schools goal achievement. Robbins, (2005), stated that working condition sensible impact on an employee's job satisfaction because the employees prefer physical surroundings that are safe, clean, and comfortable for works.

\subsubsection{Factor 5: Interpersonal relations}

Interpersonal relationships may also influence job satisfaction level. Table 10 illustrates the teachers' views on their relationships with their principals, their relationships with their colleagues; and their perceptions of their relationships with their students and parents. This table shows the mean and standard deviation of each of the variables. 
Table 10 the teachers' views on teachers' interrelationships

\begin{tabular}{|l|l|l|l|}
\hline Statements/items & N & Mean & $\begin{array}{l}\text { Std. } \\
\text { Deviation }\end{array}$ \\
\hline I am satisfied with my relationship with my colleagues & 70 & 3.81 & 1.333 \\
\hline $\begin{array}{l}\text { I am happy with my professional relationship with the school principals or } \\
\text { director }\end{array}$ & 70 & 2.37 & 1.246 \\
\hline In my school the parents are involved in their children's learning & 70 & 3.57 & 1.450 \\
\hline I am pleased with my relationships with the students' and parents & 70 & 3.59 & 1.257 \\
\hline I am happy the cooperation of worada educational coordinators. & 70 & 1.90 & .903 \\
\hline Overall score & & $\mathbf{3 . 0 4}$ & $\mathbf{1 . 2 3}$ \\
\hline
\end{tabular}

Table 10 shows the mean satisfaction or dissatisfaction rating of the teachers' views of teacher-colleague relationships. As it was observed from the table, the average mean of 3.04 indicates that the teachers were relatively satisfied with this aspect of their work. This shows that teachers in selected preparatory schools were sociable, and value their relationships with their colleagues. However, the teachers were dissatisfied with the respect they receive from their principals and with the friendly relations they had with their school directors with the mean of 2.37 and as the same to this teachers ware dissatisfied with the relationship of worada educational coordinators.

The table reveals that, in general, the teachers were satisfied with their relationship with the students and parents-the variable mean was 3.59. The mean of 3.57 indicates that, in general, the teachers were very satisfied with parents' involvement in their children's learning relationship.

The woreda educational coordinators, directors and supervisors interview result also indicates that: The majority of teachers' are poor relation with supervisors because of insufficient technical support of teachers', the way supervisors contact only to see the teachers' classroom instruction and to evaluate their work performance instead of giving instructional support and feedback. Therefore, poor relations between teachers' with supervisor, student, and management teams and within teachers' reduce success of achieving of the school goal and objectives. According to Oshagbemi (2001), individuals who perceive to have better interpersonal friendships with their co-workers and immediate supervisor lead higher levels of job satisfaction.

\subsubsection{Research question 2}

How employee/teacher's job satisfaction relates with their commitment?

This section includes the analysis of data related to teachers' job satisfaction and commitment.

To investigate the relationship between job satisfaction and commitment Pearson product correlation coefficient was used. The Pearson product moment correlation coefficient is a statistic that indicates the degree to which two variables are related to one another. The sign of correlation coefficient ( + or -$)$ indicates the direction of the relationship between -1 and +1 .

Variables may be positively or negatively correlated. A positive correlation indicates a direct and positive relationship between two variables. A negative correlation, on the other hand, indicates an inverse, negative relationship between two variables (Leary, 2004). Measuring the strength and the direction of a linear relationship that occurred between variables is, therefore, important for further statistical significance. To this end the Pearson's product moment correlation coefficient is computed for the purpose of determining the relationships between teachers' job satisfaction and commitment in selected preparatory schools.

Therefore, to answer this basic research question, Pearson correlation is calculated. The result of correlation analysis indicates the degree of relation that occurred between teachers' job satisfaction and their commitment in selected governmental preparatory school in Bale Zone. The following result indicates those teachers' respondents' shows relations between teachers' job satisfaction and commitment on selected governmental preparatory school in Bale Zone depending up on the general levels of teachers' job satisfaction and their job commitments from the questionnaire items.

Table 11: The relationship of teachers' job satisfaction and commitment

Correlations

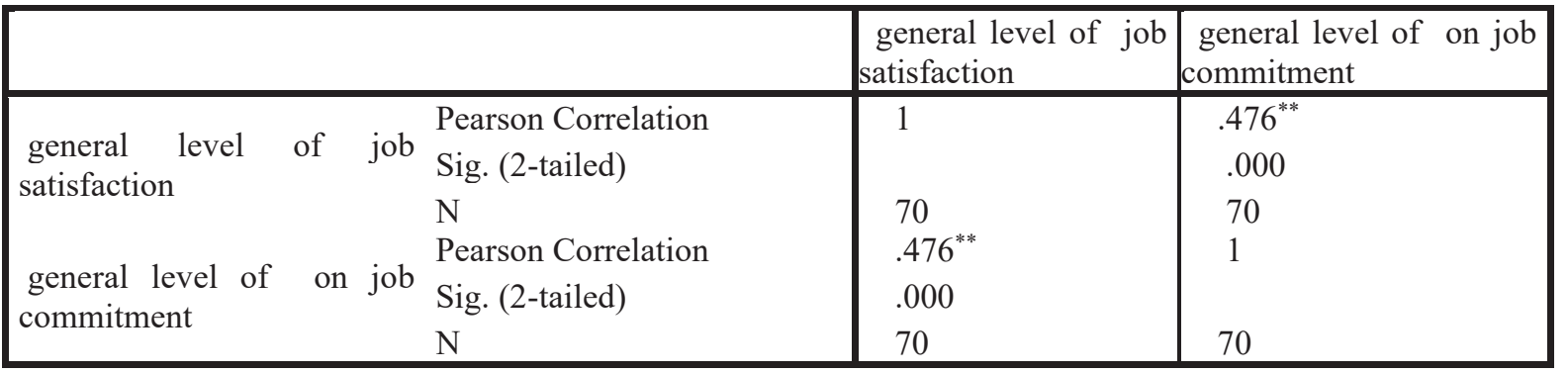

**. Correlation is significant at the 0.01 level (2-tailed). 
This output gives us a correlation matrix for the two correlations requested in the above dialog box. Note that despite there being cells in the above matrix, their correlation between level of job satisfaction and commitment on job. A Pearson correlation analysis was conducted to examine whether there is a relationship between teachers' job satisfaction with their commitment in selected governmental preparatory schools of Bale Zone. The results revealed of teachers' were a significant and positive relationship between teachers' job satisfaction and commitment $(r=.48, \mathrm{~N}=70)$. The more level of teachers' job satisfaction associated with more level of teachers' commitments and the low level of teachers' job satisfaction associated with teachers' low level of commitments in the study area. This positive correlation coefficient (0.467) indicates that there is a statistically significant $(\mathrm{p}<0.001)$ linear relationship between these two variables such that the more job satisfied a teachers' has, the highly commitment teachers' or the more job dissatisfied a teachers' has, the poor job commitment teachers'.

The interview result also indicates that teachers' job satisfaction and commitment are related in job. The more satisfied teachers' are more committed than less satisfied teachers' in the job. The current satisfaction of teachers' on the job is low because of poor facilities of educational equipments and necessary material for teaching learning in the schools, low benefits of teachers, low access of transfer of teachers from one school to other school, housing related problem, and lack of good relation between teachers' and principals' are the major causes for low satisfaction of teachers. These low teachers' job satisfaction and commitment of on the job negatively influence the school's goal and objectives.

Therefore, teachers' job satisfaction and commitment are positive and significance relation in the study area. Scott (2004) stated that, employees who have high level of job satisfaction commit their time, energy and efforts to work which result in high productivity. Mass of teachers' were not satisfied and committed in the current job in the study area.

The interview responses revealed that teachers were not satisfied to their current job. This is shows that big obstacle to achieve educational goal and objective in the study area. Therefore, without teachers' job satisfaction and commitment effectively, achieving of educational goal and objective become challenging in the area of the study. As Ofoegbu (2004) stated that, teachers are happy, devoted and committed, and in job helps them to bring their best qualities to their schools, students, parents, and the society may benefit from their services

\subsubsection{Teachers' Commitment on their Job}

This section includes the analysis of data obtained from teachers and director, supervisors and worada educational coordinate on teachers' commitments of selected governmental preparatory schools of Bale Zone. To support the second basic research questions, the commitment questions were presented in the questionnaire item to be responded by teachers and principals, principals and supervisors in the following table.

Table: 12 Teachers' Commitment on their Job

\begin{tabular}{|l|l|l|l|}
\hline Statements/items & N & Mean & Std. Deviation \\
\hline Affective Commitment on the Job & 70 & 2.18 & 1.37 \\
\hline Continuance Commitment on the Job & 70 & 2.23 & 1.22 \\
\hline Normative Commitment on the Job & 70 & 2.21 & 1.19 \\
\hline Overall score & & $\mathbf{2 . 2 1}$ & $\mathbf{1 . 2 7}$ \\
\hline
\end{tabular}

Scales $; \leq 1.49=$ Strongly Disagree, $1.5-2.49=$ Disagree, $2.5-3.49=$ Undecided

$-4.49=$ Agree,$\geq 4.5=$ strongly agree .

The following graph also shows the overall teachers' commitment on their job. 


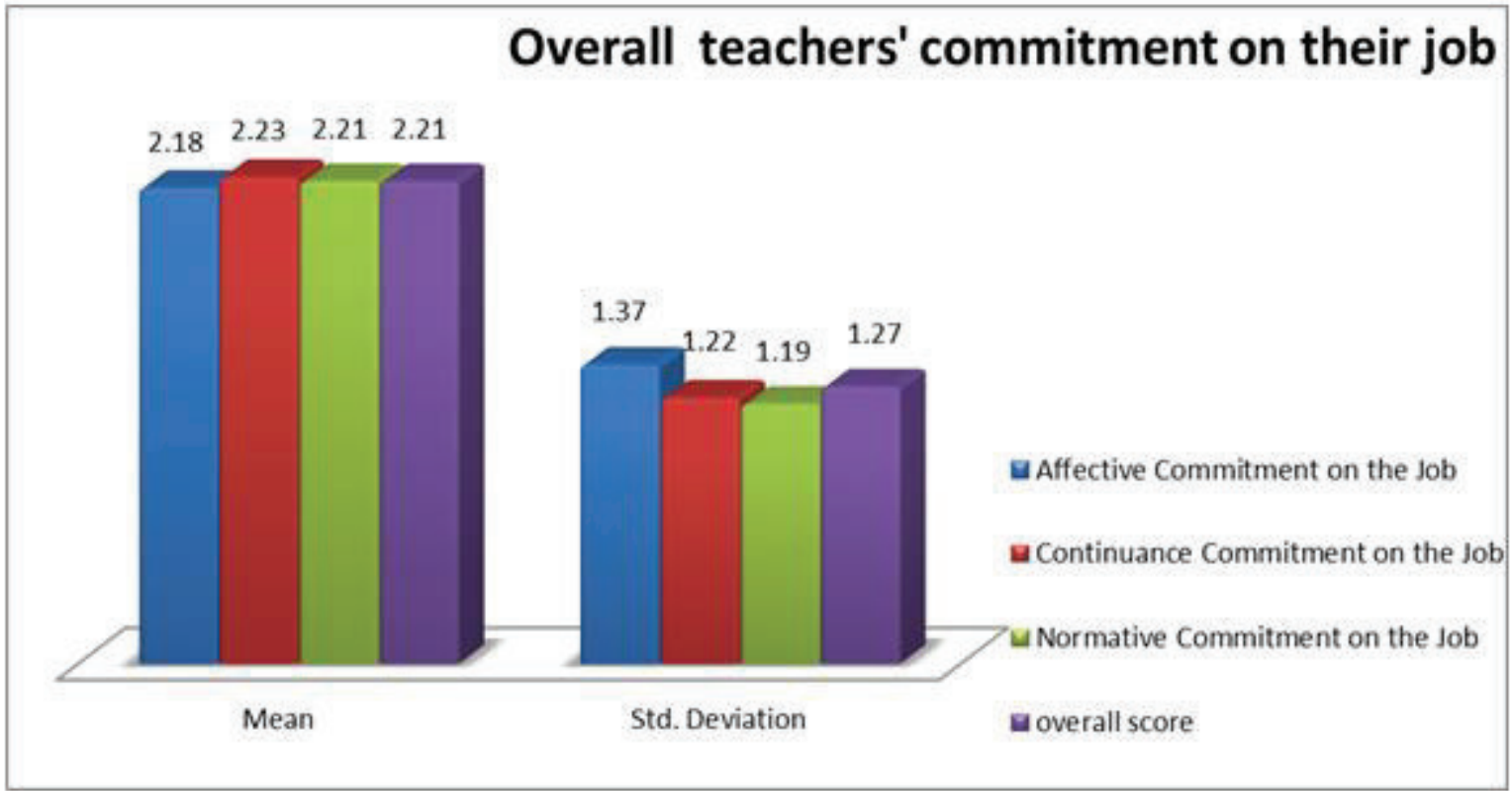

As table 12 reveals that, overall mean score teachers is 2.18 with a standard deviation of 1.37 indicates the level of disagreement within teachers' affective commitment.

An interview result also indicates that: Majority of teacher' in the school expects external force to do their job, and poorly interested to achieve school goal. The levels of tolerance between teachers' in different issues in the schools are also poor because low commitment of teachers' on the job. This show that majority of teachers are not strongly contributes to the success of school goal. Poor contribution of teachers' on the school goals and objectives make ineffective on the student achievement.

Results from table 12 reveals that overall mean score teachers is 2.23 with a standard deviation of 1.22 indicates the level of disagreement within teachers' continuance commitment. This shows teachers' responses for continuance commitment relatively better than the responses of directors, and supervisors in the study area. Furthermore, an interview results also indicates that: More of teachers' stay in teaching profession because of lack of other alternative to change other sector, and other high income and benefits job relatively betters to teaching. This shows that mass of teachers in the teaching profession in the study area are not interested to continued with teaching profession. Lack of interest to continue with teaching profession is may minimize commitment of teachers' on job. The low level of continuance commitment of teachers has an influence on the school goals and objectives.

As table 12 indicates, overall mean score teachers' is 2.21 with a standard deviation of 1.19 indicates the level of disagreement within teachers' normative commitment. An interview result also indicates that: the majority of fresh teachers' are low moral responsibility on than more experienced teachers' on the current job because of many of them have low satisfaction on the job. Therefore, low moral responsibility of teachers' is negatively influence the achievement of school goals and student performances. High moral responsibility of teachers' in the job increases the academic achievement of student.

\subsubsection{Research question 3}

What is the effect of teachers' job satisfaction on their commitment?

What is the effect of Job satisfaction on employees' commitment to selected Governmental preparatory schools of bale zone?

To investigate the effect teachers' job satisfaction on their commitment linear regression coefficient was used. Regression is the estimation or prediction of values of one variable from known values of one or more variables. The variable whose value is to be estimated or predicted is known as dependent/predicted variable; while the variables whose values are used to determine the value of the dependent variable are called independent/predictor variables.

For each value of the independent variable (job satisfaction), the distribution of the dependent variable (teachers' commitment must on job) be normal. The variance of the distribution of the dependent variable should be constant for all values of the independent variable. The relationship between the dependent variable and each independent variable should be linear, and all observations should be independent.

Therefore, to answer this research question, linear regression is calculated. The result analysis indicates the job satisfaction has a significant on teachers' commitment in selected governmental preparatory school in Bale Zone. The following result indicates those teachers' respondents' shows the effect of teachers' job satisfaction 
on their commitment on selected governmental preparatory school in Bale Zone depending up on the general levels of teachers' job satisfaction and their job commitments from the questionnaire items.

Table 13: Linear regression Model Summary for job satisfaction and employees' commitment

\begin{tabular}{|l|l|l|l|l|l|l|l|l|l|}
\hline Model & $R$ & R Square & $\begin{array}{l}\text { Adjusted } \\
\text { Square }\end{array}$ & & & & $\begin{array}{l}\text { Std. Error of } \\
\text { the Estimate }\end{array}$ & &
\end{tabular}

a. Predictors: (Constant), general level of job satisfaction

b. Dependent Variable: general level on job commitment

The results of linear regression model summary in table 13 shows that the $(\mathrm{R}=.476$, $\mathrm{R}$-square $=0.227)$ which is equivalent to $46.6 \%$ and $22.7 \%$ of the amount of variance explained by the model which indicated that job satisfaction has a significantly influence on employees'/teachers' commitment. Furthermore, the DurbinWatson value of 1.637 was obtained indicating that autocorrelation assumption was met as the value was in the acceptable range of $1.5>\mathrm{d}>2.5$.

Based on the above, it can be revealed that good job satisfaction will develop teacher commitment in school's institution. The more develop teacher job satisfaction automatically he/she will get more awareness in his organizational commitment. Therefore, there is an effect of job satisfaction towards teacher organizational commitment. Finally, it can be assumed that there is a direct effect towards teacher teachers' commitment.

Employee satisfaction was found to have positive effect on commitment levels. Thus, the more an employee is satisfied with the job the more commitment will be exhibited toward work and the organization which in the end will culminate in quality of service. Job satisfaction means as a level of one's exited feeling emerged by a reward or job. On the other side, teacher teachers' commitment is the shape of attitude; manner takes side towards the school operational in order to achieve the goals, vision and mission that had been set before.

Table 14: ANOVA results for job satisfaction and employees' commitment

\begin{tabular}{|ll|l|l|l|l|l|}
\hline Model & & Sum of Squares & Df & Mean Square & F & Sig. \\
\hline \multirow{4}{*}{1} & Regression & 19.325 & 1 & 19.325 & 19.966 & .000 \\
& Residual & 65.818 & 68 & .968 & & \\
& Total & 85.143 & 69 & & & \\
\hline
\end{tabular}

a. Dependent Variable: general level on job commitment

b. Predictors: (Constant), general level of job satisfaction

The results of ANOVA indicate that $(\mathrm{F}=19.966, \mathrm{P}=0.000)$, since $\mathrm{P}<0.005$ the alternative Question was accepted because the level of significance show that there was enough evidence that the slope of population regression line was not zero, thus, job satisfaction has a significant influence on employees'/teachers' commitment. Therefore, the above value indicates that the of teachers' job satisfaction has an effect on their commitment.

\section{Coefficients}

\begin{tabular}{|c|c|c|c|c|c|c|c|c|}
\hline \multirow[t]{2}{*}{ Model } & & \multicolumn{2}{|c|}{$\begin{array}{l}\text { Unstandardized } \\
\text { Coefficients }\end{array}$} & \multirow{2}{*}{\begin{tabular}{|l|}
$\begin{array}{l}\text { Standardized } \\
\text { Coefficients }\end{array}$ \\
Beta
\end{tabular}} & \multirow{2}{*}{$\mathrm{t}$} & \multirow{2}{*}{ Sig. } & \multicolumn{2}{|c|}{$\begin{array}{l}95.0 \% \text { Confidence } \\
\text { Interval for B }\end{array}$} \\
\hline & & B & $\begin{array}{l}\text { Std. } \\
\text { Error }\end{array}$ & & & & $\begin{array}{l}\text { Lower } \\
\text { Bound }\end{array}$ & $\begin{array}{l}\text { Upper } \\
\text { Bound }\end{array}$ \\
\hline & (Constant) & 1.419 & .255 & & 5.574 & .000 & .911 & 1.927 \\
\hline 1 & $\begin{array}{l}\text { general level of job } \\
\text { satisfaction }\end{array}$ & .501 & .112 & .476 & 4.468 & .000 & .277 & .725 \\
\hline
\end{tabular}

a. Dependent Variable: general level on job commitment

The Unstandardized Coefficients column gives that an indication of what would happen were to increase one of the independent variables by exactly one unit. This indicated, if the general level of teachers' job satisfaction were to increase by one unit, we would expect general level on job commitment to increase by 0.501 units. The standard errors are used to calculate the t-values. If we take the unstandardized coefficient of general level of job satisfaction (0.501) and divide this by its standard error (0.0112), we obtain a value that is approximately the t-value of the 4.468 indicated in the table A one standard deviation increases in general level of teachers' job satisfaction would yield a 0.476 standard deviation increase in the teachers' commitment on current job this association is statistically significant $(p<0.005)$

F- Test of Regression coefficient, indicated that independent variable (job satisfaction) associated with it is contributing significantly to the variance accounted for in the dependent variable (commitment job). As a result, 
the above value indicates that of teachers' job satisfaction has an effect on their commitment.

\subsection{Discussion}

The results of the study showed that salary and benefits had an effect on the job satisfaction of the teachers. Both quantitative and qualitative data clearly showed that the majority of the teachers were not satisfied with their remuneration packages. Of all the factors that were investigated in this study, salary and benefits had the lowest mean satisfaction rating. Salary, fringe benefits, and advancement and promotion were reported by the teachers as the major sources of their job dissatisfaction (see sections 4.3.1.1 and 4.3.1.3). Their dissatisfaction with their poor salaries was influenced by the inflation rates in preparatory schools. In addition, no other fringe benefits, such as transport allowances, health insurances and medical care are provided. Moreover, promotion opportunities are limited and, according to the teachers, not free from bias. All these and other unfavorable conditions have a strong negative impact on the job satisfaction of the teachers. This dissatisfaction impacted on quality teaching.

In order to achieve specific goals, the employee is likely to expend more energy and effort into the job. In addition incentive is something that paved the way for particular course of action. When incentives are offered and thereafter the incentive will be given to the employee as a reward when the goal is met (Ahuja \& Shukla, 2007). The perceived low salaries affected the value, respect, and status teachers had in their societies. It appears that the salaries the teachers earned were not sufficient to fulfill the teachers' lower order physiological or biological needs (Maslow, in section 2.5.1). Thus, the teachers often took on other jobs and were less committed to their teaching.

In the role of administrative support and leadership, the majority of the teachers surveyed were not satisfied with the most leadership and administrative support practices (see Tables 6). The administrative support and leadership practices which were viewed and perceived negatively and as most dissatisfying, namely: poor administrative support at the schools, leading to decreased teacher commitment; the lack of the availability of instructional materials; inefficient administrative support with regard to student disciplinary problems; unfair decisions, and the evaluation of the teachers' work by the school administration, an non-transformational the school principals' lack of ability to identify the teachers' strengths; a lack of respect for the teachers by the students and the parents; and for the recognitions given, the teachers were not satisfied.

In line with the above-mentioned results, Baker (2007:83) reported that the teacher respondents in his study viewed administrative support as inadequate, and this was one of the primary reasons for the teachers leaving the profession. In their study of teacher commitment trends in Hong Kong, Choi and Tang (2009) found that the teacher respondents appeared uncommitted to their job, as was found in this study, due to their perceived lack of administrative support. In contrast to the above, a USA study by Chang, et al. (2010:5-6) revealed that administrative support was one of the most significant and strongest predictors of teachers' job satisfaction, in comparison to other variables. This was similar to the findings of Ma and McMillan (1999:46), namely that school administration positively affected the teachers' job satisfaction.

The 1994 Ethiopian education policy declared that non-political education would be provided at all education levels. The teachers in the sample, however, thought that they were exposed to political influences, due to their school directors' ideologies. This confirms previous views. For example, an education sector development programmed indicated the need for improvement in school leadership (Psacharopoulos \& Patrinos, 2004). The document indicated that irrelevant and uncoordinated training courses by the school leaders had not succeeded in overcoming the challenges related to school leadership, and that it remained poor. This study shows that poor leadership had a negative effect on the job satisfaction of teachers.

This study found that many of the preparatory school teachers spoke positively about their profession and the value of their profession for the development of their students. This finding is consistent with the findings in studies by Bolin (2007:56); Jyoti and Sharma (2006:354). The results of this study, however, also showed that the teachers were not happy with the opportunities for personal development (see Table 8). They reported that teaching did not give the majority of the teachers the opportunity to continue their education. According to Kim (2005:669), individuals that score high on aspects related to the work itself, have high possibilities for reporting satisfaction.

The data from both the interview and questionnaire revealed that the teachers were unhappy with their limited participation in decision-making. This lack of freedom inhibited the teachers to assume full responsibility to solve school-related problems. This lack of responsibility and dissatisfaction among the school teachers were reflected in the teachers' demotivation. They confessed to a reluctance to actively participate in school activities, they adopted uncreative teaching styles, and were resistant to change, and to contributing more than was expected of them. This confirms Boey's (2010:2) statement that when teachers are not given the opportunity to solve practical school problems, and do not receive support from their superiors, this can contribute to job dissatisfaction and demotivation.

The results of the present study (see Tables 10), indicate that the preparatory school teachers who 
participated in the study were generally undecided with some of their interpersonal relationships. More than half of the teacher respondents in this study indicated that the support given to them by their directors was dissatisfying. Therefore, the teachers reported that they were dissatisfied with their relationships with the school directors. This may be related to their perceptions that the schools management had poor leadership styles and revealed non-supportive behavior that significantly inhibited job satisfaction. Accordingly, Bolin (2007:63) found that school principals who place high pressure on teachers were identified as a major cause of teacher dissatisfaction. However they reported deriving most satisfaction from their interpersonal relationships with their colleagues and other staff members. The majority of the teacher respondents mentioned students and parents relationships as a poor satisfactory aspect of their teaching job. The above is in confirmation of Ting's observation (1997:315) many years ago that cooperative and supportive colleagues contribute to higher levels of job satisfaction. A good interpersonal relationship with other teachers is one of the preconditions of being positive about the job of teaching. This finding confirm with Garrett and Hean (2001:367) they found that the teachers' positive relationships with management contributed to job satisfaction.

In order to observe the Relationship between teachers' job satisfaction and commitment, a Pearson correlation analysis was computed to examine the relation between teachers' job satisfaction with their commitment in selected governmental Preparatory Schools in Bale Zone. The results revealed significant and positive relationship between teachers' job satisfaction and commitment $(\mathrm{r}=.48, \mathrm{~N}=70)$. The same tools computed for directors, supervisors and worada educational coordinate were also result indicate significant and positive relationship between teachers' job satisfaction and commitment $(\mathrm{r}=.54, \mathrm{~N}=16)$. The correlation was strong and positive relationship in both teachers' directors, supervisors and worada educational coordinate. Higher levels of teachers' job satisfaction were associated with higher levels of commitment in the study areas.

In the selected governmental Preparatory Schools affective, continuance and normative commitment are poor. The result indicates that most of scored in likert scale mean averages are below three. The interview responses indicate that teachers' were poorly committed in their job. As the result large numbers of teachers' in the school expect external force to do their job, poorly interested to achieve school goal and objective, and low level of tolerance between teachers and school administration in different issues. In addition to these, teachers stay in teaching profession they do not have another alternative to change other sector, and low moral responsibility in their job.

In addition, to investigate the effect teachers' job satisfaction on their commitment linear regression coefficient was used. The results of linear regression model summary shows that the $(\mathrm{R}=.476, \mathrm{R}$-square $=0.227)$ which is equivalent to $46.6 \%$ and $22.7 \%$ of the amount of variance explained by the model which indicated that job satisfaction has a significantly influence on employees'/teachers' commitment. Therefore, there is an effect of job satisfaction towards teacher organizational commitment. Finally, it can be assumed that there is a direct effect towards teacher teachers' commitment.

The results of ANOVA indicate that $(\mathrm{F}=19.966, \mathrm{P}=0.000)$, since $\mathrm{P}<0.005$ the alternative Question was accepted because the level of significance show that there was enough evidence that the slope of population regression line was not zero, thus, job satisfaction has a significant influence on employees'/teachers' commitment. Therefore, the above value indicates that the of teachers' job satisfaction has an effect on their commitment.

\section{Summary, Conclusions and Recommendations}

This chapter deals with summary, conclusion and recommendations. In this section, first, summary of the study and the major findings were made. Second, conclusions of the fundamental findings were drawn. Lastly, some possible and plausible recommendations were forwarded on the basis of the findings of the study.

\subsection{Summary}

The main purpose of this study was to assess the effect of Teachers job satisfaction on their commitment in selected governmental preparatory school of Bale Zone. In order to achieve this purpose, the study attempted to answer the following research questions.

1. What is the level of job satisfaction of employees/teachers' in Bale Zone selected Governmental Preparatory Schools?

2. How employees' job satisfaction relates with their commitment in Bale Zone selected Governmental Preparatory Schools?

3. What is the effect of employees' job satisfaction on job commitment in Bale Zone selected Governmental Preparatory Schools?

In this study, the researcher designed the descriptive research design. To answer these research questions, mixed approach procedure for collecting, analyzing, and "mixing" both quantitatively and qualitatively. To this effect the study is conducted in 5 purposely selected preparatory schools of Bale Zone.

A total of $92(72 \%)$ teachers were selected through systematic sampling technique for selecting participants 
as a sample of the study. Furthermore, 12(71\%) directors and supervisors and 9(69\%) Woreda education coordinators were selected through census, since they have direct relation in supporting and observing teachers' activities. To gather necessary information on the issue 68 questionnaires items were distributed to teachers and 17 questionnaires were distributed to directors, supervisors and Woreda education coordinators. In addition, unstructured interview was made with directors, supervisors and Woreda education coordinators to extract indepth information regarding to teachers job satisfaction and commitment. Accordingly, the questionnaire and interview results obtained from the research participants were analyzed and interpreted using SPSS version 20. Therefore, based on the analysis of the data (questionnaires and interview result), the following findings were obtained from the study.

As finding shows that the general value (lowest) means satisfaction rating scale was for the salary and benefits factor. The mean value of this factor was 1.77, a value obtained by aggregating the mean values of each of the statements of Tables 5. It can clearly be seen that the teachers' experience of this factor was towards the disagreement or dissatisfaction scale and value.

Table5 also shows that the other key factor for the level of teachers' job satisfaction is management. This aspect focuses on administrative support, school management and leadership, and recognition. To illustrate this, the mean value of this factor was 2.28, indicating that; in general, teachers were relatively disagree/dissatisfied level in their work places. Moreover, advancement and promotion can be considered as factors which include the growth and development, job security and upward status, with mean factor of 2.17. This value indicate that teachers were in a dissatisfied level with advancement and promotion

Besides to this, work characteristics which can include workload, the nature of the work and responsibility is found as a factor. As it was illustrated in table 5, the mean value of this factor was 2.8. This implies that teachers were relatively undecided/neutral level with work load and this is the highest mean of all the factors. The interpersonal relationships factor is considered as a factor with mean of 3.04. This factor includes the relationship of teachers with their principal, colleagues, students and parents. This indicated that the teachers were slightly undecided/neutral level with interpersonal relationships. Finally, Table 5 illustrates that, the mean and standard deviation value of over general score (value) for all factors indicates the level of dissatisfied (2.41) and strongly dissatisfied value with 1.09 respectively.

In order to examine the relation between teachers' job satisfaction and their commitment in selected governmental Preparatory schools of Bale Zone, Pearson correlation analysis was made. The results revealed that, there was a significant and positive relationship between teachers' job satisfaction and commitment (r $=.476, \mathrm{~N}=70$ ). Similarly, this is consistent with directors', supervisors' and wereda educational coordinators' response through interview. Therefore, the correlation was positive relationship as teachers', directors, supervisors and wereda education office coordinators responses.

\subsection{Conclusions}

Based on the above research findings, the following conclusions were made. It is possible to conclude that the teachers' job satisfaction has an effect on their commitment. It can also be concluded that the level of teachers' job satisfaction, the relationship between teachers' job satisfaction and commitment are related in the following ways.

$>$ The results related to the teachers' satisfaction with their salaries showed that $76 \%$ of the teachers who participated in this study were dissatisfied. Their views indicated the belief that their salaries did not cover all their basic needs. The most dissatisfying aspects of their remuneration related to the fact that they believed their salaries did not compare well with the qualifications they hold, with the salaries paid by other similar professions, with their efforts, and with experiences.

$>$ Similarly, the teachers in this study also have negative views of their fringe benefits. Most of the participant teachers were dissatisfied with the fringe benefits they were provided with the amount, the system and the type of allowances given.The fulfillment of these factors is the requirement for the basic aspects of the work factors to overcome. Further, this study showed that the absence of satisfactory salary and benefits were negatively affecting the teachers' satisfaction with their job.

$>$ The study also revealed that the other fundamental reason, in addition to salary and benefits, for the low job satisfaction of teachers in selected Schools was the inability of the school management and administration to effectively address the teachers' demands for supportive and fair leadership. The teachers expressed dissatisfaction with the administrative support practices prevailing in the schools, which related to the availability of instructional materials, student disciplinary problems, the evaluation of the teachers' work, and school security. Among the interviewed teachers, poor administrative support was considered to be the second most dissatisfying issue.

$>$ With regard to school leadership practices, poor school policies, unfair decisions, the nontransformational style of the principal leadership, and the unfair treatment of teachers were found to be the most dissatisfying issues. Moreover, the teachers reported that they were highly dissatisfied with non- 
participatory decision-making by non-supportive and incompetent school directors.

$>$ With respect to advancement and promotion, the preparatory schools teachers indicated their dissatisfaction with the opportunities for promotion, professional advancement, and fair evaluation by their supervisors and directors. In addition, the interviewed were of the opinion that the promotion practices were unfair, and were based on political party membership.

$>$ As regards their workload, the teachers expressed their satisfaction with the workload they had at their school. However, with respect to work characteristics, the teachers found the essential tasks associated with teaching a dissatisfying aspect of their work. Both the quantitative and the qualitative data showed that the teachers were unhappy with the responsibilities associated with teaching. The teachers were also dissatisfied with the amount of freedom they had in decision-making.

$>$ The results in relation to interpersonal relationships showed that the teachers were generally undecided with this component of their work. The study identified the interpersonal relationships with colleagues and/or staff members as the most satisfying. With regard to the teachers-directors relationships, the teachers indicated in both the quantitative and the qualitative data, they were dissatisfied with the support they received from the school directors. The majority of the interviewed also reported that teachersdirectors relationships have a negative influence on their job satisfaction.

$>$ Based on collected and analyzed data, the relationship between teachers' job satisfaction and their commitment related positively. Additionally, a higher level of teachers' job satisfaction was associated with higher levels commitment in the study areas (schools). The level of teachers' job satisfaction and their commitment are not satisfactory in the study area. The low level of teachers' job satisfaction and their commitment in the study area make the teaching-learning process become ineffective. The findings also revealed the school's weakness on different aspects that have relation to enhance teachers' job satisfaction and commitment on the achievement of educational goals and objectives of schools.

$>$ Based on the results and findings, the level of teachers commitment on their job in the study area are low as the level of affective, continuance, and normative commitment of teachers' in the study area are not committed. Furthermore, the majorities of teachers in the school expect external force to do their job, and poorly interested to achieve school goal and objectives. The mass of teachers' also is not preferred to stay with teaching profession and low moral responsibility of in teaching' profession.

$>$ Teachers' job satisfaction was found to have positive effect on their commitment levels. Thus, the more teachers' is satisfied with the job, the more commitment on their job toward the effective educational quality. The study found that job satisfaction has a positive significant effect on teachers' commitment in the study area.

\subsection{Recommendation}

Based on the conclusions and findings of this study, the recommendations for improving the teachers' job satisfaction with their commitment of selected governmental preparatory schools of Bale Zone are as follows:

* Since the teachers were highly dissatisfied with their salaries, the Ethiopian government, educational leaders at different levels and the Ethiopian Teachers' Association should work cooperatively and understand the importance of implementing appropriate salaries and benefits for teachers. In addition to this the concerned body should design mechanisms for non-salary incentives to teachers that may include transport allowances, health insurance, and low-interest loans to buy and build their own homes, as well as other accommodation for teachers.

* Inadequate salaries have serious negative implications for the morale, status, and effectiveness of teachers, the quality of the education system, and for the development of the country as a whole. So, the education system managers should analyze the living conditions in Ethiopia, and advise those in charge of setting the teacher salaries. The government or the education leaders can put mechanisms in place, in collaboration with the community, donors, and other organizations for the direct funding to schools, and to teachers in particular.

* Zone education department and Woreda education offices should make special attention for teachers' job satisfaction and their commitment in the job. The attention area should focus on the teachers' personal development and training, fair benefits and incentive, constructive continuous support, fair and equitable promotion, in the area of professional responsibility...etc. This helps the teachers to increase the level of job satisfaction and maximize their level of commitment on students' achievement.

* As finding indicates that external job satisfaction relatively more influence than internal factor of job satisfaction. Therefore, schools, woreda education offices and Zone education department should work together with other governmental sectors, non-governmental organizations and local community to enhance teachers' job satisfaction.

* Unsatisfactory level of normative commitment of teachers in the job resulted in low moral responsibility of teachers in the profession. Therefore, school, woreda and other concerned bodies should maximize teachers, 
levels of professional moral responsibility in the job by facilitating attractive teaching learning environment in school in collaborates with community, governmental and non-governmental organization. This promotes teachers in their job as well as improves the student achievement.

* To increases teachers' job satisfaction and their commitment, it is important that schools and woreda should allocate sufficient budget to supple necessary materials and equipment that is vital for practical use in the laboratory, library, ICT center...etc. The Schools directors and wereda Education office should create conducive work environment and positive work competition among teachers based on their performance weekly/monthly or semester fairly.

* Teachers need to be empowered through both in-service and regular training program, and by using educational opportunities to maximize their problem-solving abilities. Education leaders need to closely supervise and establish systems to monitor and evaluate whether rules and regulations are being implemented transparently by the school directly. Therefore, better to focuses on foster teachers' commitment by encouraging teachers' in the job satisfaction by fair and equitable rewards to achieve school goals.

* The school directors should have quality and participatory school policies in place, and make fair decisions, and they should promote open discussions and the sharing of good experiences between themselves and the teachers. They should follow a transformational style of leadership, based on feedback from teachers. What is most important for improving teaching and learning at school is the management and leadership styles and qualities that the school principals display in their schools. Addressing the factors that negatively affect the job satisfaction and commitment of teachers should be a primary concern of the school directors.

* From this study results showed that job satisfaction has positive influence on employee/teachers' commitment. This indicates the need for efforts made by the school leadership to pay attention to employee or teachers' satisfaction in performing works by providing challenging work to employees and adjust the awards are worth, a conducive working environment to provide satisfaction to employees, co-workers in the schools are mutually supportive, employment and individual personality goes well and the job satisfaction of employees during work is assured.

* The education stakeholders need to give appropriate recognition to teachers' works. It should also be the task of the stakeholders to raise awareness of the importance of the teaching profession for the society. The appreciation and affection given to teachers for the work they do has an indeterminable value. This, in addition to improving the professional status of teachers, would have strong positive implications for the improvement of quality in education systems. The teachers must be given the chance to express their views, through media programs to develop their profession, and the respect from the society.

\section{References}

Aamodt, M.G. (2004). Applied Industrial/Organizational Psychology (4th edition). USA Thomson/Wadsworth

Adams, JS. (1965). Toward an understanding of inequity. Journal of Abnormal and Social Psychology, 67(5):422-436.

Ahuja, K. K. \& Shukla, B. (2007). Human resource management. India: Kalyani publishers

Amos, TL. Pearson N.J., Ristaw A. \& Ristaw, L. (2008). Human resource management (3rd ed.). Cape Town: Juta \& Co.

Anderson, N. (2001). Organizational Psychology. London: Sage Publishers

Armstrong, M (2006). A handbook of human resource management practice,(10 Edition) London, Kogan Page Publishing, p. 264.

Ataphia, D. A.(2011). The Impact of Environment on Productivity in Secondary Schools, African Journal of Education and Technology, Vol. 1, No.1, pp. 116-122.

Aziri, B. (2011). Job satisfaction: A literature review. Management Research \& Practice. 3(4), 77-86. Retrieved 10-12, 2016 from: http://mrp.ase.ro/no34/f7.pdf

Bagraim, J. J. (2003). The dimensionality of professional commitment. SA Journal of Industrial Psychology,29(2), 6 -9. http://www.sajip.co.za/index.php/sajip/article/viewFile/104/100

Baker, VD. 2007. Relationship between job satisfaction and the perception of administrative support among early career secondary choral music educators. Journal of Music Teacher Education, 17:77-91.

Barnes and Conti Associates (2009). Building working relationships: Constructive engagement, negotiation and conflict management.

Beck N.M. \& Wilson J.H.(2000). Development of affective organizational commitment: A cross-sequential examination of change with tenure. Journal of Vocational Behavior. 56,114-136.

Bennell, P. \& Akyeampong, K. (2007). Teacher motivation in Sub-Saharan Africa and South Asia. London: Department for International Development.

Bernstein, D. A., \& Nash, P. W. (2008). Essentials of psychology (4th ed.). Boston: CengageLearning. Retrieved from http://books.google.com/books?id=4Do-bFrt9tUC 
Best and kahn (2012). Research in education: 9th edition, New Delhi university of Illinois at prentice-hall of India private limited.

Boey, EK. 2010. Teacher empowerment in secondary schools: a case study in Malaysia. Munchen: Herbert Utz Verlag GmbH.

Boggie, T. (2005). Unhappy employees [Electronic version]. Credit Union Management, 28(4), 34-37.

Bolin, F. 2007. A study of teacher job satisfaction and factors that influence it. Chinese Educational Society, 40(5):47-64.

Borg, M. G., Riding, R. J., \& Falzon, J. M. (1991). Stress in teaching: A study of occupational stress and its determinants, job satisfaction and career commitment among primary schoolteachers. Educational Psychology, 11(1), 59-75.

Bratton, J. \& Gold, J. (2007). Human resource management theory and practice. New York: Palgrave.

Buitendach, J. \& De Witte, H. (2005).Job insecurity, extrinsic and intrinsic job satisfaction and affective Organizational Commitment of maintenance workers in a parasternal.South Africa

Caprara, G. V., Barbaranelli, C., Steca, P., \& Malone, P. S. (2006). Teachers' self-efficacy beliefs as determinants of job satisfaction and students' academic achievement: A study at the school level. Journal of school psychology, 44(6), 473-490. Journal of Business Management, 36, 27- 37.

Celep, C. (2000). Teachers ${ }^{\text {ee }}$ Organizational Commitment In Educational Organizations. Trakya University. Edirne,TURKEY. National Forum of Teacher Education Journal, l (10E),(3). ERIC NO:ED452179.

Cockcroft, J. (2001). Job satisfaction and organizational commitment: An empirical investigation in the Free State branches of a service organization. Unpublished honours thesis, University of the Free State, Free StateCrosswell, L. (2006). Understanding Teacher Commitment in Times of Change.Doctoral Thesis

Choi, PL. \& Tang, SYF. 2009. Teacher commitment trends: cases of Hong Kong teachers from 1997 to 2007. Teaching and Teacher Education, 25(5):767-777.

Cohen, A. (2007). Multiple commitments in the workplace: An integrative approach.Mahwah, NJ: Erlbaum.

Coladarci, T. (1992).Teachers' Sense of Efficacy and Commitment to Teaching.The Journal of Experimental Education, 60 (4), 323-337

Collin, A. (20011). Human resource management: A contemporary approach. (3rd Ed.). UK: Pearson Education Limited.

Correnti, R., Miller, RJ. \& Rowan, B. (2002). What large-scale survey research tells us about teacher effects on student achievement: insights from the prospects study of elementaryschools. Teachers College Record, 104(8):1525-67.

Creswell, J. W. (2012). Educational Research: Planning, Conducting and Evaluating Quantitative and Qualitative Research. 4th Ed. Pearson Education, Inc. University of Nebraska- Lincoln.

Danielson, L. (2002). Developing and retaining quality classroom teachers through mentoring. The Clearing House, 75 (4), pp. 183-185.

Dinham, S. and Scott, C. (2000).Moving into the third outer domain of teacher satisfaction.Journal Educational administration, 38, No. 4, 379- 396.

Ellickson MC, Logsdon K (2001). Determinants of job satisfaction of Municipal Government employees. State and Local government Review. 33(3):173-184.

Firestone, W.A. \&Rosenblum, S. (1988)..Building commitment in urban high schools.educational Evaluation and P 'Hey Analysis, IQ, 285-299.

Garrett, R. \& Hean, S. 2001. Sources of job satisfaction in science secondary education in Chile. Compare: A Journal of Comparative and International Education, 31(3):363-379.

Gedefaw, K (2012). Job satisfaction of secondary school teachers in Ethiopia.University ofSouth Africa (PhD, Dissertation).

Gehlawat, M., \& Gupta, M. (2013) Job Satisfaction and Work Motivation of Secondary School Teachers in Relation to Some Demographic Variables: A Comparative Study.Educationia Confab Vol. 2, No. 1, pp. 1019.

Glassman, M., McAfee, RB. \& Quarstein, VA. (1992). The situational occurrences theory of job satisfaction. Human Relations, 45(8):859-874.

Graham, M.W., \& Messner, P.E. (1998). Principals and job satisfaction [Electronic Version]. The International Journal of Educational Management, 12(5), 196-202.

Green, J. (2000). A study of job satisfaction of community college chairpersons. Unpublished doctoral thesis. Blacksburg, VA: Virginia Polytechnique Institute and State University.

Hargreaves, A. (1994), Changing Teachers, Changing Times: London, Cassell.

Harrison, D. A., D. Newman, and P. L. Roth. (2006). How important are job attitudes? Meta analytic comparisons of integrative behavioral outcomes and time sequences. Academy ofManagement Journal 49:305-25.

Herzberg, F., Maunser, B. \&Snyderman, B.(1959). The Motivation to Work. New Jersey: Transaction Publishers. 
Herzberg, F. 1966. Work and the nature of man. Cleveland, OH: The World Publishing Company.

Hewstone, R. \&Stroebe, B. (2001).Social Psychology. Victoria: Blackwell Publishing House.

Hongying, S. (2008).Literature review of teacher job satisfaction.Chinese Education and Society, 40(5):11-16.

Hoy, WK. \& Miskel, CE. (1996). Educational administration: theory, research, and practice. (5th ed.). New York: McGraw-Hill.

Jyoti, J. \& Sharma, RD. (2006). Job satisfaction among school teachers. IIMB Management Review, 18(4):349363.

Jaiyeoba, AO. \&Jibril, A. (2008).A study of job satisfaction of secondary school administrators in Kano state, Nigeria.An International Multi-Disciplinary Journal, 2(2): 94-107.

Judge, T. A., \& Kammeyer-Mueller, J. D. (2011). Implications of core self-evaluations for a changing organizational context. Human Resource Management Review, 21(4), 331-341.

Jyoti, J. \& Sharma, RD. (2006).Job satisfaction among school teachers.IIMB Management Review, 18(4):349363.

Jyoti, J. \& Sharma, RD..(2009). Job satisfaction of university teachers: an empirical study. Journal of Services Research, 9(2):51-80.

Kaliski, B.S. (2007). Encyclopedia of Business and Finance, Second edition, Thompson Gale, Detroit, p. 446.

Kim, S. 2005. Gender differences in job satisfaction of public employees: a study of Seoul Metropolitan government, Korea. Sex Roles, 52(9/10):667-681.

Klecker, B. \& Loadman, W. E. (1996). Exploring the relationship between teacher empowerment and teacher job satisfaction. ERIC Clearinghouse on Educational Management (ERIC Digest, No. ED 400 254).

Kreitner, R., \&Kinicki, A. (1998).Organizational behavior: (4th Edition). New York: McGraw-Hill Inc.

Kreitner, R., \& Kinicki, A. (2001). Organizational behavior: (5th ed.). New York: Mc Graw- Hill Inc.

Kondalkar, V. G. (2007). Organizational behavior. India: New Age International (P) Lid

Kothari, C. R. (2011). Research Methodology; Methods and Techniques. $2^{\text {nd }}$ Revised Edition. New Delhi: New age international publishers.

Kothari, C. R. (1990). Research Methodology; Methods and Techniques. $2^{\text {nd }}$ Revised Edition. New Delhi: New age international publishers.

Larson, C.E and Lafasto, F.M (1989). Team work: What must go right / what can go wrong. Newbury Park: California sage.

Lawler, E.E. (1973). Motivation in work organizations. California: Brooks/Cole, Monterey.

Leary, M. R. (2004). Introduction to behavioral research methods. USA: Pearson education, inc.

Leithwood, K. (2006). Teacher working conditions that matter: Evidence for Change. Toronto: University Avenue. Elementary Teachers ${ }^{\text {ee }}$ Federation of Ontario

Luthans, F. (2005). Organizational Behavior, (10 ${ }^{\text {th }}$ ed). New York. McGraw-Hill Irwin.

Ma, X. \& McMillan, R. 1999. Influences of workplace conditions on teachers' job satisfaction. Journal of Educational Research, 93(1):39-47.

Maheshwari, S., Bhat, R., \&, A. (2007). Implications of human resource practices and other structural factors on commitment of public medical professionals. India. Retrieved October 22, 2008,

Marks, S. (1994). Intimacy in the public realm: The case of co-workers. USA: Social Forces Co.

Meyer, J.P. \& Allen, N.J. (1991). A three component conceptualization of organizational commitment. Human Resource Management Review, 1, 61-89.

Meyer, J.P. \& Allen, N.J. (1997). Commitment in the workplace, theory, research and application. California: Sage.ctober 22, 2008, from http://www.iimahd.ernet.in

Meyer, J.P ,Allen, N.J and Best (2002). Commitment in the workplace, theory, research and application.California: Sage.

Meyer, J., \& Allen, N. (1997).Commitment in the workplace: Theory, research, and application. Thousand Oaks, CA: Sage.

Monyatsi .(2012). The level of the job satisfaction of teachers in botswana. European Journal of Educational Studies 4(2), 2012219.

Mueller, C. W., \& Kim, S. W. (2008). The contented female worker: Still a paradox?. In K. A. Hegtvedt and J. Clay-Warner (Eds.), Justice: Advances in group processes volume 25(pp.117-150). Bingley, UK: Emerald Group Publishing Limited.

Mullins, L.J. (1999). Management and organizational behavior: (5th ed.). Great Britain: Pitman publishing

Mwamwenda, T. S. (1995). Job Satisfaction among Secondary School Teachers in Transkei. South African Journal of Education, 15, pp. 84-87.

Naylor, J. (1999). Management. Harlow: Prentice hall.

Nazari, K. \& Emami, M. (2012). Analysis of relation between organizational commitment and professional commitment. Elixir Human Res. Mgmt. 51 (2012) 10661-10664. Retrieved August 20, 2013 from http://papers.ssrn.com/sol3/papers.cfm?abstract_id=2298898 
Ngimbudzi, F. W. (2009). Job Satisfaction Among Secondary School Teachers in Tanzania: The Case of Njombe District. A Thesis for award of Master in Education at University of Jyvaskyla.pp. 101.

Norton, M.S., \& Kelly, L. K. (1997).Resource allocation: Managing money and people, eye on education. New York: Larchment.

Ofoegbu, FI. (2004). Teacher motivation: a factor for classroom effectiveness and school improvement in Nigeria. College Student Journal, 38(1):81-89.

Ogunsanya, M. (1983). supervision of instruction in education. Teaching manual for course EdU 710. National Open University of Nigeria

Ololube, NP. (2006). Teacher job satisfaction and motivation for school effectiveness: an assessment. Available at: http://www.usca.edu/essays/vol182006/ololube.pdf. Accessed on 31 January 2011

Omari, I. M. (2011).Concepts and Methods in Educational Research. Dar es Salaam: Oxford University Press.

Oshagbemi, T. (2001). How satisfied are academics with the behaviour/supervision of their line managers? The International Journal of Educational Management, 15(6) 283-291.

Oshagbemi, T. 2001. Gender differences in the job satisfaction of university teachers. Women in Management Review, 15(7):331-343

Pinder, CC. (2008). Work motivation in organizational behaviour. (2nd ed.). New York: Psychology Press.

Psacharopoulos, G. \& Patrinos, HA. 2004. Returns to investment in education: a further update. Education Economics, 12(2):111-134.

Robbins, S.P., Odendaal, A., \& Roodt, G. (2003). Organisational behavior:(9th ed.). Cape Town: Prentice-Hall International

Saeed, M. M. \& Asghar, M. A. (2012). Examining the relationship between training, motivation and employees job performance: The moderating role of person job fit. Journal of basic and applied scientific research Vol.2 (12) 12177-12183

Schermerhorn, J. R., Hunt, J. G., Osborn, R. N. \& Uhl-Bien, M. (2011). Organizational behavior. (11th ed.). Asia: John Wiley \& Sons, inc.

Scott M (2004). Mississippi State University Extension Service Agents. Perceptions of Fundamental Job Characteristics and their level of Job Satisfaction. Unpublished Masters Thesis State University.

Shovel, M. (2007). Macmillan English Dictionary for Advance Learners $\left(^{\text {nd }}\right.$ Ed). London: A \& C Black Publishers.

Simon (2011). What is job security and does it really exist?Retrieved from www.simonstapleton.com/wordpress/2011/02/12 what-is-job-security-and-does-it- reallyexist

Shann, M. H. (2001). Professional Commitment and Satisfaction among Teachers in Urban Middle schools. The Journal of Educational Research, 92 No. 2, 67- 73.

Shen, J., Leslie, J. M., Spybrook, J. K., \& Ma, X. (2012). Are principal background and school processes related to teacher job satisfaction? A multilevel study using Schools and Staffing Survey 2003-04. American Educational Research Journal, 49(2), 200-230.

Smart, J. (1990). A casual model of faculty turnover intentions. Review of Higher Education, 31(5), pp. 405-424.

Smith, T.(2007). Job Satisfaction in America: Trends and Socio-Demographic Correlates.Chicago: NORC.

Spector, P. E. (1997). Job Satisfaction: Application, assessment causes and consequences. Thousand Oaks, CA: Sage Publications.

Spector, P. E. (1997). Measurement of human service staff satisfaction.American Journal of Community Psychology, 13 (6), 693-711.

Statt, D. (2004). The Dictionary of Business Management: Third edition, Routledge Publishing, Detroit, p. 78.

Sumra, S. (2004).The Living and Working conditions of teachers in Tanzania: A research report. Dar es Salaam: HakiElimu and Tanzania teachers Union. Retrieved in January 8, 2014, available at: http://www.Hakielimu. Org/living_work_cond.pdf.

Tella A., Ayeni CO., \&Popoola SO (2007).Work Motivation, job satisfaction and organizational commitment: Library personnel in Academic and Research Libraries in OYO State Nigeria.

Ting, Y. 1997. Determinants of job satisfaction of federal government employees. Public Personnel Management, 26(3):313-334.

Thungu, J., Wandera, K., Gachiel., L \&Alunde, G. (2008). Mastering of PTE Education.Nairobi: Oxford University Press East African Limited.

Troman, G. and Woods, P. (2000). "Careers under stress: Teacher adaptations at a time of intensive reform", Journal of Educational Change, Vol. 1, pp. 253-275.

Vaughan, G. M., \& Hogg, M. A. (2011). Social psychology (6th edn.). Frenchs Forest, NSW: Pearson Australia

Von Glinow, A. M, \& Mcshane, L. S. (2005). Organizational Behaviour 3 Edition. New York: McGrawHill/Irwin Co.

Vroom, VH. (1964). Work and motivation. New York: John Wiley and Sons, Inc.

VSO (2002). What makes teachers tick? A Polity Research Report on Teachers'Motivation in Developing 
Countries. London: Volunteer Services Overseas (VSO).

Ware, H., \& Kitsantas, A. (2007). Teachers and collective efficacy beliefs as pedictors of professional commitment. Journal of Educational Research, 100(5), 303-310. Retrieved November 8, 2010, from Academic Source Premier Database

Wright, B., and S. Kim. (2004). Participation 's influence on job satisfaction: The importance of job characteristics. Review of Public Personnel Administration 24 (1): 18-40.

Yamane T. Statistics, An Introductory Analysis. $2^{\text {nd }}$ ed. New York: Harper and Row, 1967.

Zembylas, M., \&Papanastasiou, E. (2004).Job satisfaction among school teachers in Cyprus.Journal of Educational Administration, 42, 357-374.

Wood, O. R. (1976) A research project: Measuring job satisfaction of the community college staff. Community College Review, 3(3), pp. 56-64. 